\title{
From Micro to Long: Non-Coding RNAs in Tamoxifen Resistance of Breast Cancer Cells
}

\author{
Jéssica Fernanda Barazetti ${ }^{1}$, Tayana Shultz Jucoski ${ }^{1}$, Tamyres Mingorance Carvalho ${ }^{1}$, Rafaela Nasser Veiga ${ }^{1}$, \\ Ana Flávia Kohler ${ }^{1}$, Jumanah Baig ${ }^{2,3}$, Hend Al Bizri ${ }^{2}$, Daniela Fiori Gradia ${ }^{1}$ (D) Sylvie Mader 2,3,* \\ and Jaqueline Carvalho de Oliveira ${ }^{1, *}$
}

1 Post-Graduation Program in Genetics, Department of Genetics, Federal University of Parana, Curitiba 81530-000, Parana, Brazil; jessicabarazetti@ufpr.br (J.F.B.); tayanajucoski@ufpr.br (T.S.J.); tamyrescarvalho@ufpr.br (T.M.C.); rafaela.veiga@ufpr.br (R.N.V.); anakohler@ufpr.br (A.F.K.); danielagradia@ufpr.br (D.F.G.)

2 Department of Biochemistry and Molecular Medicine, University of Montreal, Montreal, QC H3T 1J4, Canada; jumanah.baig@umontreal.ca (J.B.); hend.al-bizri@umontreal.ca (H.A.B.)

3 Institute for Research in Immunology and Cancer, University of Montreal, Montreal, QC H3T 1J4, Canada

* Correspondence: sylvie.mader@umontreal.ca (S.M.); jaqueline.carvalho@ufpr.br (J.C.d.O.); Tel.: +55-41-99554-9609 (J.C.d.O.)

check for updates

Citation: Barazetti, J.F.; Jucoski, T.S.; Carvalho, T.M.; Veiga, R.N.; Kohler, A.F.; Baig, J.; Al Bizri, H.; Gradia, D.F.; Mader, S.; Carvalho de Oliveira, J. From Micro to Long: Non-Coding RNAs in Tamoxifen Resistance of Breast Cancer Cells. Cancers 2021, 13, 3688. https://doi.org/10.3390/ cancers 13153688

Academic Editors: Anupama Munshi, Christos Papadimitriou,

Dimitrios Mavroudis and Nicholas Pavlidis

Received: 31 March 2021

Accepted: 15 July 2021

Published: 22 July 2021

Publisher's Note: MDPI stays neutral with regard to jurisdictional claims in published maps and institutional affiliations.

Copyright: (c) 2021 by the authors. Licensee MDPI, Basel, Switzerland. This article is an open access article distributed under the terms and conditions of the Creative Commons Attribution (CC BY) license (https:// creativecommons.org/licenses/by/ $4.0 /)$.
Simple Summary: Breast cancer is a disease that affects thousands of women around the world. Adequate treatment depends on the characterization of breast cancer subtypes. Tumors that are positive for the estrogen receptor represent the most common subtypes and have the best prognosis. However, many patients relapse due to resistance to tamoxifen, one of the main drugs used for these subtypes. In this study, our goal is to discuss a class of molecules that have been directly linked to the tamoxifen resistance process but is still underexplored: the non-coding RNAs (ncRNAs). We have reviewed ncRNAs that have been associated with different processes of resistance to tamoxifen in order to stimulate a discussion about the importance of knowing and understanding the role of these molecules in breast cancer and their relevance to clinical applications.

Abstract: Breast cancer is the most commonly diagnosed cancer and the leading cause of cancer mortality among women. Two thirds of patients are classified as hormone receptor positive, based on expression of estrogen receptor alpha $(E R \alpha)$, the main driver of breast cancer cell proliferation, and/or progesterone receptor, which is regulated by ER $\alpha$. Despite presenting the best prognosis, these tumors can recur when patients acquire resistance to treatment by aromatase inhibitors or antiestrogen such as tamoxifen (Tam). The mechanisms that are involved in Tam resistance are complex and involve multiple signaling pathways. Recently, roles for microRNAs and lncRNAs in controlling ER expression and/or tamoxifen action have been described, but the underlying mechanisms are still little explored. In this review, we will discuss the current state of knowledge on the roles of microRNAs and lncRNAs in the main mechanisms of tamoxifen resistance in hormone receptor positive breast cancer. In the future, this knowledge can be used to identify patients at a greater risk of relapse due to the expression patterns of ncRNAs that impact response to Tam, in order to guide their treatment more efficiently and possibly to design therapeutic strategies to bypass mechanisms of resistance.

Keywords: breast cancer; estrogen receptor; tamoxifen; endocrine resistance; ncRNA; lncRNA; microRNA

\section{Introduction}

Breast cancer is the most commonly diagnosed cancer and the leading cause of cancer mortality among women [1]. Breast tumors can be classified in clinical practice as hormone receptor and/or HER2 positive (HR+ and/or HER2+) vs negative (HR- and/or HER2-) by immunohistochemical detection or as luminal A, luminal B, HER2-enriched and basal-like 
according to transcriptome profiling using gene signatures such as PAM50 [2]. Hormone receptors include the estrogen receptor alpha $(E R \alpha)$, the main driver of breast cancer cell proliferation, and the progesterone receptor (PR), a gene regulated by ER, both acting as hormone-dependent transcription factors. HR+ tumors are positive for ER and/or progesterone receptor (PR). The HR+HER2- subtype is the most common, representing around $73 \%$ of all occurrences, and generally has a good prognosis. The HR+HER2+ subtype has a higher cell proliferation index and usually a more aggressive phenotype, constituting $11 \%$ of occurrences [3].

Breast cancer classification and the development of targeted therapies has considerably improved treatment options and patient prognosis [4]. The subtypes that are positive for the estrogen receptor usually respond to endocrine therapies targeting the estrogen receptor (ER) pathway, based on antiestrogens, which include selective ER modulators (SERMs) and selective ER downregulators (SERDs), or on aromatase inhibitors (AIs), which prevent endogenous production of estrogens [5]. One of the most commonly prescribed first-line SERM for hormone responsive subtypes is tamoxifen [6]. Tamoxifen (Tam) is a highly efficient SERM widely used for treatment of all stages of breast cancer in pre- and postmenopausal women. It binds ER and blocks its transcriptional activity. Tam use in the clinic has led to a drop in the recurrence rate by 50\% at 5 years and 30\% lower during the next 5 years [7]. However, approximately 50\% of advanced ER-positive breast tumors are intrinsically resistant to tamoxifen and about $40 \%$ of patients receiving adjuvant tamoxifen eventually relapse [8].

The mechanisms that are involved in Tam resistance are complex and involve multiple signaling pathways [9,10]. Recently, roles for microRNAs and lncRNAs in controlling ER expression and/or tamoxifen action have been described, but the underlying mechanisms are still little explored. In this review, we will discuss the current state of knowledge on the roles of microRNAs and lncRNAs in the main mechanisms of tamoxifen resistance.

\section{Estrogens and Estrogen Receptor Alpha}

Estrogens are mitogenic hormones that play crucial roles in normal breast development, but also in carcinogenesis. They are predominantly synthesized in the ovaries of premenopausal women and to a lesser extent in peripheral tissues, including breast tissue. In postmenopausal women, estrogens are only produced in extragonadal peripheral tissues [11].

The estrogen receptor alpha $(\mathrm{ER} \alpha)$ is one of the most significant biological markers for the diagnosis/prognosis of breast cancer and its accurate detection is important for therapeutic choice in BC patients. ER $\alpha$ is member of the nuclear receptor superfamily of ligand activated transcription factors [12,13]. There are two functionally distinct ERs: ER $\alpha$ and ER $\beta$. The human ESR1 gene, which encodes ER $\alpha$ is located on chromosome 6 while the human ESR2 gene, coding for ER $\beta$, is located on chromosome 14 [14,15]. These receptors have different and often opposite effects and the proliferative response caused by estrogens in breast epithelial cells is thought to be the result of a balance between $\operatorname{ER} \alpha$ and $\operatorname{ER} \beta$ signaling. While ER $\alpha$ has a proliferative effect on breast cells, acting as a transcriptional activator of genes associated with cell survival and proliferation, the role of ER $\beta$ is usually antiproliferative and proapoptotic [16,17]. However, ER $\alpha$ is overexpressed in ER+ tumors while ER $\beta$ expression is reduced.

The ER $\alpha$ is a $66 \mathrm{kDa}$ nuclear protein and its transcriptional activity is ligand-dependent. Estrogens bind to the receptor and change its conformation, inducing binding to specific target DNA sequences called estrogen response elements (EREs) $[12,13]$. On DNA, the estrogen-ER $\alpha$ complex interacts with coregulatory proteins, modulating the transcription of genes involved in cell cycle regulation, DNA replication, cell differentiation, cell survival, and angiogenesis $[14,18]$. The estrogen-ER complex can also act on non-nuclear pathways through the regulation of membrane receptors (for example, IGFR, FGFR, and HER2) and kinases (for example, mitogen activated protein kinases, receptor tyrosine kinases, PI3K, AKT, mTOR, Src, and CDK4/6) [14,18]. 
The ESR1 gene also encodes ER variants, such as ER $\alpha 36$ and ER $\alpha 46[19,20]$. ER $\alpha 36$ has a novel noncoding exon as its first exon and also a unique 27 amino acid domain that replaces the last 138 amino acids in ER $\alpha 66$, and as a result lacks both transcription activation domains (AF-1 and AF-2) [21]. ER $\alpha 46$ is a truncated form that lacks the transactivation function domain 1 (AF1) and functions to inhibit the AF1 activity of the full length $\mathrm{ER} \alpha 66$ [22].

\section{Mechanisms of Tamoxifen Resistance}

Despite the clinical efficacy of Tam, intrinsic or acquired resistance is an important obstacle limiting the success of ER + breast cancer patient treatment. It is a challenge that needs to be overcome to improve the prognosis of these patients. The main mechanisms of resistance to tamoxifen can be divided according to different causes: mechanisms that involve genetic mutations and lead to loss or gain of function of the receptor and mechanisms that modulate other protumorigenic pathways, including other receptors involved in estrogen's pathway of action. Here we will highlight some of these mechanisms, with a focus on targets of non-coding RNAs implicated in resistance to tamoxifen.

A recently identified mechanism that interferes with the action of Tam is the emergence of mutations that alter the structure and function of the receptor. Constitutively active mutants can recruit coactivators in the absence of estrogens [23], leading to resistance to aromatase inhibitors, which act by depleting estrogen production. The efficacy of antiestrogens with these mutant ER forms is also reduced in a manner that is mutation and antiestrogen-specific [24]. On the other hand, since Tam's function is mediated by binding to the ER, loss of ER expression and activation of ER-independent growth are also important mechanisms of tamoxifen resistance [25]. The latter can occur through amplification or overexpression of downstream effectors of the ER proliferative program, such as the transcription factor cMyc [26] or the cell cycle regulator CCND1 [27-30].

ER isoforms, without gene mutations, may also be associated with Tam resistance. Although tamoxifen is an antagonist of ER $\alpha 66$, it activates ER $\alpha 36$. This activation might play critical roles in intrinsic and acquired Tam resistance [31]. Additionally, the ER- $\alpha 46$ variant enhances sensitivity to estrogens in breast cancer cells [22].

Disruption of the balance between ER $\alpha$ coactivators and corepressors is associated with poor prognosis and Tam resistance. Tamoxifen induces a conformational change of $\mathrm{ER} \alpha$ that blocks coactivator recruitment and favors the recruitment of corepressors. Some mutations, for example in corepressors, may be frequent in resistant cells [32].

Loss of ER may also be triggered by epigenetic mechanisms. For instance, ZEB1 and ZEB2, two transcription factors that trigger the epithelial mesenchymal transition (EMT), contribute to tumor malignancy [33]. Their suppression through in vitro regulation by miRNAs and lncRNAs was able to inhibit EMT and increase sensitivity of breast cancer cells to Tam [33]. HDACs (histone deacetylases), which remove acetyl groups of histones, can also modulate ER $\alpha$ expression [34]. Overexpression of $H D A C 1$ results in the loss of ER $\alpha$ in ER+ MCF7 breast cancer cells [35]. Intriguingly, treatment with HDAC inhibitors also suppresses ER $\alpha$ expression in ER+ breast cancer cell lines [36] while divergent conclusions have been reached concerning their impact on ER- cells [37,38].

Some of the cellular mechanisms related to Tam resistance involve alternative oncogenic signaling pathways that can provide tumors with estrogen-independent stimuli for proliferation and survival (Figure 1). An example is the activation of the ERBB2 pathway (Erb-B2 tyrosine receptor kinase 2 or HER2), known to reduce sensitivity to tamoxifen [39,40]. RBP2 (retinoblastoma-binding protein 2), also known as KDM5A (lysine demethylase 5A), physically interacts with ER, increases the stability of the EGFR and HER2 proteins, and promotes activation of the PI3K/AKT pathway, inducing tamoxifen resistance [41]. 


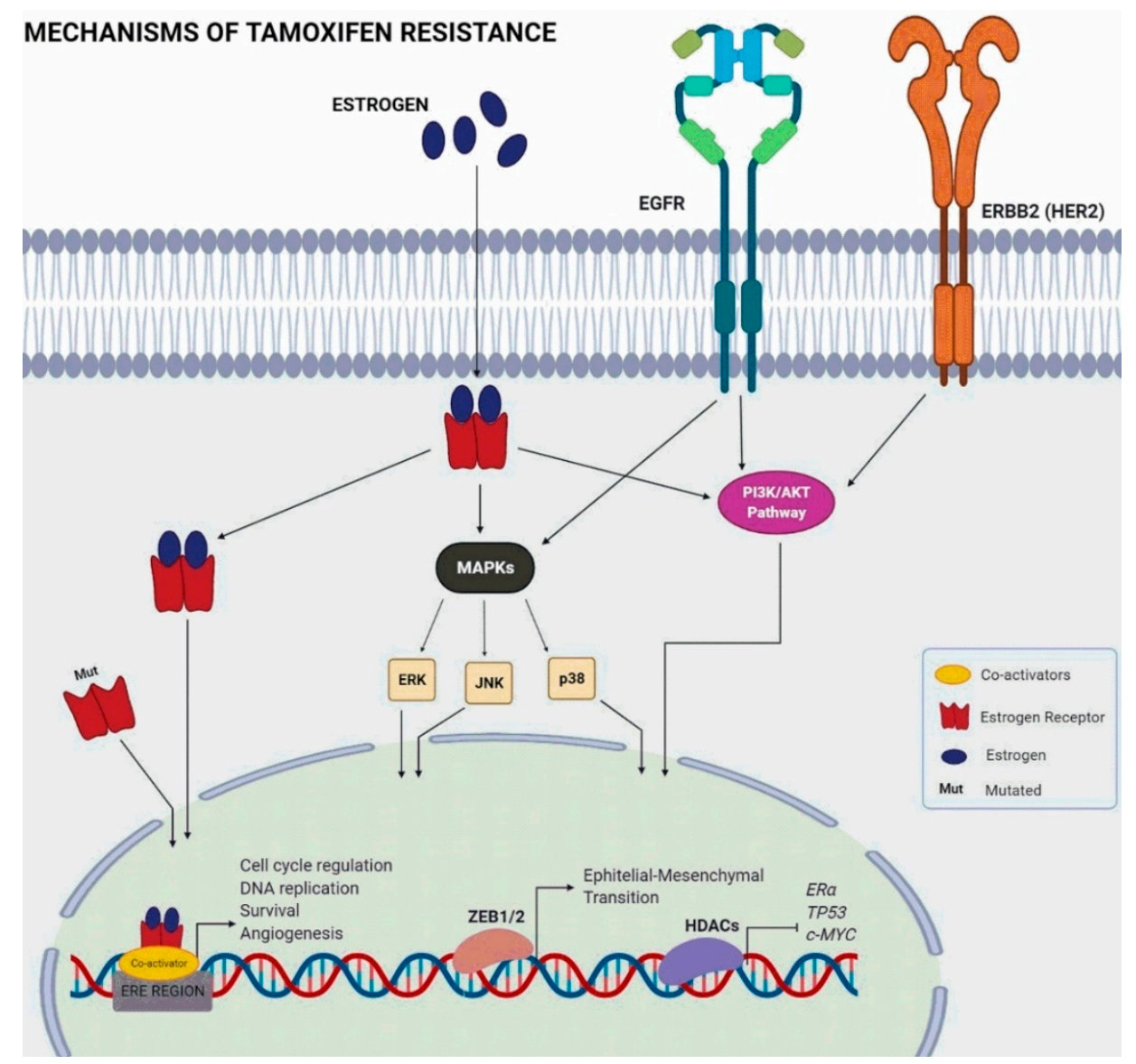

Figure 1. Estrogen signaling and pathways that interfere in tamoxifen resistance.

The phosphoinositide 3-kinase/Akt/mammalian target of the rapamycin (PI3K/Akt/ mTOR) pathway is a cell signaling pathway that plays an important role in controlling cell cycle, survival, and cell growth [42]. The PI3K/AKT/mTOR pathway is dysregulated in many types of cancers. In breast cancer, it can lead to the resistance to endocrine therapy [43]. Indeed, inhibiting this pathway improved the effectiveness of tamoxifen in cultured cells [44].

The MAPK (mitogen-activated protein kinase) pathways, including extracellular signal-regulated kinase (ERK), c-jun N-terminal kinase (JNK), and p38MAPK, also regulate many cellular functions including growth, differentiation, and survival as part of intracellular signaling cascades activated by membrane receptors. The suppression of ERK and p38 signaling increased cell sensitivity to tamoxifen in vitro [45].

Another resistance mechanism is associated with a lesser known estrogen receptor, the GPER (G-protein coupled estrogen receptor), which has a different structure from the two canonical ERs (ER $\alpha$ and $E R \beta)$. GPER is a transmembrane receptor capable of mediating proliferative signaling through binding of estrogen or antiestrogens and is expressed in $50-60 \%$ of breast cancer tissues [39]. Signaling through GPER activates metalloproteinases and induces the release of heparin-binding EGF, which binds and activates EGFR leading to downstream activation of signaling molecules, such as ERK1 and ERK2 [46].

Thus, defects in several signaling pathways can lead to resistance to Tam. The study of non-coding RNAs that interfere with either ER expression or with pathways involved in Tam resistance has added another layer of complexity to these mechanisms.

\section{Non-Coding RNAs}

Advances in sequencing technologies and computational approaches in the past few decades revealed that $75-85 \%$ of the genome is transcribed, although less than $3 \%$ of the 
human genome represents coding gene exons [47-52]. The remaining transcripts are noncoding RNAs (ncRNAs) and can be divided in subclasses. Ribosomal and transfer RNAs are the best known non-coding RNAs. However, in the past decade, increasing attention has been given to other classes of non-coding RNAs such as microRNAs, long non-coding RNAs, and circular RNAs, among others, notably for their roles in the regulation of gene expression and chromatin structure.

MicroRNAs (miRNAs/miRs) are small (approximately 18-25 nucleotide long) noncoding RNAs that, most of the time, interact with the $3^{\prime}$ UTR of target mRNAs and posttranscriptionally regulate their expression by mRNA cleavage or by inhibition of translation [53]. Dysregulated miRNA expression is frequently associated with hallmarks in cancer development and resistance to therapies $[54,55]$. In breast cancer, several reports suggested that miRNAs might have an essential role in Tam resistance by the regulation of genes in previously described pathways [56-60].

Long non-coding RNAs (lncRNAs) are a class of non-coding transcripts that are over 200 nucleotide long [61,62]. LncRNAs have similarities with mRNAs in terms of length, transcription and splicing structure, yet lack protein-coding potential due to the absence of sizeable open reading frames, although some lncRNA may encode small functional peptides $[61,63,64]$. LncRNAs are located in intergenic, intronic or exonic loci, and can be imprinted. They may overlap with protein-coding genes in a sense or antisense direction [63,65-68].

There is growing evidence indicating that many lncRNAs are expressed in a temporal and tissue-specific manner and play a role in gene regulation through different mechanisms [62,66-70]. Accumulating evidence suggests that some lncRNAs may be key regulators of biological processes like imprinting [71,72], pluripotency [73-76], cell differentiation [74,75], DNA damage response [68], cell apoptosis [70], inflammatory and immune responses [77]. Mutations, polymorphisms or altered expression patterns of lncRNAs have been associated with the progression and/or severity of several diseases, including breast cancer [68,78-81]. More recently, lncRNA deregulation has also been associated with Tam resistance in breast cancer cells [82].

\section{Integrative Review: Methodology}

An integrative review of the literature on miRNAs and lncRNAs involved in tamoxifen resistance was performed. A literature research on PubMed, Science Direct, Medline and Web of Science database using the following keywords: "long non-coding RNA/ lncRNA" OR "microRNA/miRNA/miR" AND "tamoxifen resistance/tam-resistance/endocrine resistance" was done by more than one author. The inclusion criterion was original research papers with lncRNA or miRNA related to tamoxifen resistance. Case reports, review articles, and meta-analyses were not considered and articles repeated in several databases were counted only once (Figure 2). Thereby, we obtained lists of miRNAs and lncRNAs possibly related to tamoxifen resistance. Both lists were then evaluated according to title, abstract, and full text. The articles wherein miRNAs/lncRNAs were not the focus or where these molecules were not properly evaluated or not evaluated in the context of tamoxifen resistance were excluded.

All steps and exclusion criteria and the numbers of publications selected at each step for analysis in this review are listed in Figure 3. 

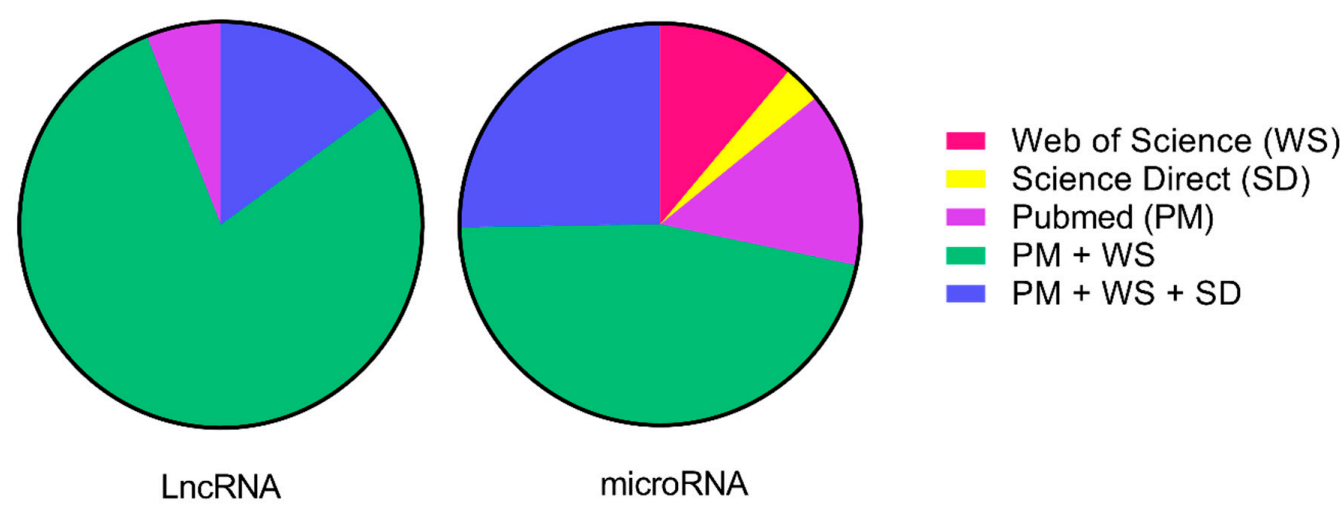

Figure 2. Percentage of articles found in one or more literature sources. A literature search was performed on PubMed (PM), Science Direct (SC), Medline (MD), and Web of Science (WS) databases using the following keywords: "long non-coding RNA/lncRNA" OR “microRNA/miRNA/miR" AND “tamoxifen resistance/tam-resistance/endocrine resistance". We represented the final numbers of publications selected in this review. The Medline source had no studies after applying the exclusion criteria.

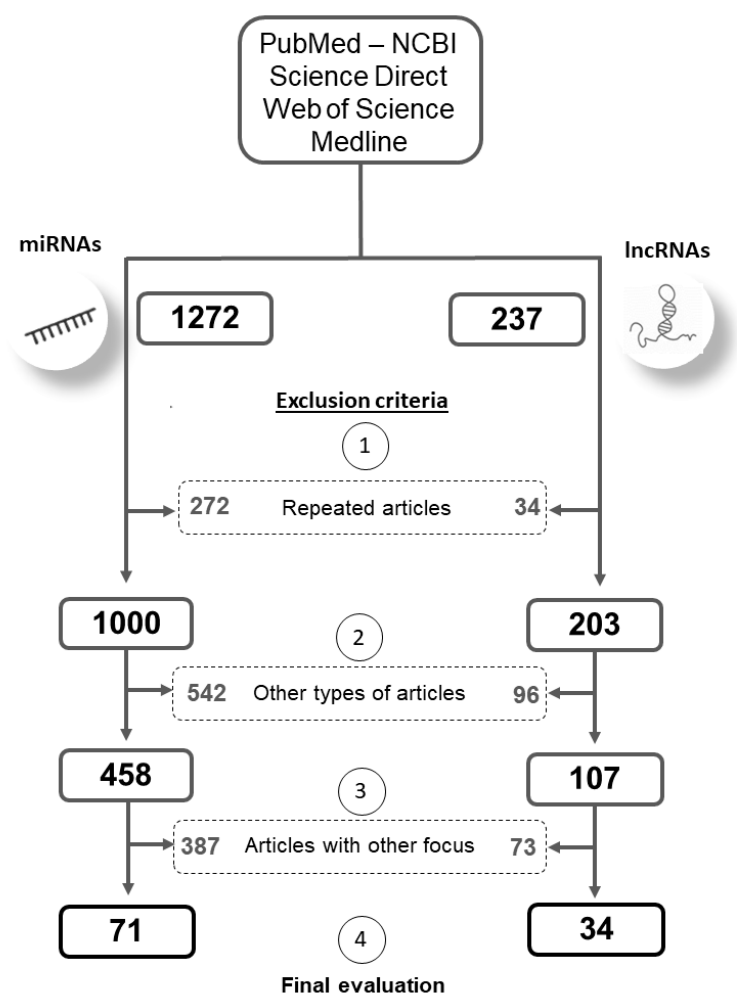

Figure 3. Schematic representation of study selection divided by microRNAs and long non-coding RNAs in four databases (PubMed, ScienceDirect, Medline, and Web of Science). Keyword variants were used to perform the search (long non-coding RNA; lncRNA; microRNA; miRNA; miR) AND (tamoxifen resistance; tam-resistance; endocrine resistance). Selection was performed based on inclusion criteria: original research papers with miRNA or lncRNA related to tamoxifen resistance, and exclusion criteria: (1): repeated articles between databases that were counted more than once; (2): articles not classified as original research papers, such as: case reports, reviews, book chapters, and meta-analyses; (3): papers wherein miRNAs/lncRNAs were not the focus and these molecules were not properly evaluated. The values inside the central dotted rectangles are the numbers of articles excluded in each selection step, and the external rectangles comprise the final numbers after each selection step. In the end, we obtained two lists of articles for miRNAs and lncRNAs that were analyzed individually (4). 


\section{Results}

After a systematic review of the literature according to our research strategy, we gathered information about 75 different miRNAs in a total of 71 studies and about 22 different lncRNAs in a total of 34 studies. Detailed information about these ncRNAs is summarized in Table 1 (miRNAs) and Table 2 (lncRNAs).

\section{1. microRNAs and Tamoxifen Resistance}

Mechanistic studies about Tam resistance have been conducted mainly in breast cancer cell lines, in which resistance can be induced by long term culture in the presence of Tam or its active derivate 4-hydroxy-tamoxifen. Several studies $[83,84]$ mapped differentially expressed miRNAs in matched resistant and sensitive ER+ breast cancer cells, such as MCF-7/MCF-7R. Most MCF7-R cells were generated with long-term exposure to 4-hydroxytamoxifen [85].

Almost a quarter of the selected studies involving miRNAs highlighted the miR$221 / 222$ family, the first and most studied oncomiR cluster related to tamoxifen resistance. Tamoxifen resistant cells exhibit increased expression of miR-221/222 and knockdown of miR-221/222 restores cell sensitivity [86-88]. MiR-221 and miR-222 interact with the 3'-UTR of the ESR1 gene and decrease ER $\alpha$ mRNA and protein levels [87,89-94]. Interestingly, miR-221/222 expression is conversely downregulated by ER $\alpha$ agonists, suggesting the existence of a reciprocal negative feedback [92]. However, in addition to ESR1, miR$221 / 222$ also downregulates other genes such as p27Kip1 and PTEN, which may explain their proliferative effects in Tam resistant cells. ERBB2 signaling further led to increased levels of $\mathrm{miR}-221 / 222$ and decreased levels of ER $\alpha[86,92]$.

ESR1 is also a known target of several miRs besides miR-221/222 [87,89,90,94]. Altered expression of these molecules could be an advantage for tumor progression, especially in combination with the activation of oncogenic pathways. Kim and colleagues found that upregulation of miR-500a-3p promotes tamoxifen resistance by downregulating ESR1 [89]. Other miRNAs overexpressed in tamoxifen-resistant cells and having ESR1 as a direct target include miR-335-3p and miR-335-5p [90].

On the other hand, miR-135a, which directly targets ESR1, was downregulated in Tam resistant cells [94]. Downregulation of miR-192-5p promotes tamoxifen resistance by upregulating $L Y 6 \mathrm{~K}$ [89] and miR-873 is downregulated in tamoxifen-resistant cells, targeting CDK3, which phosphorylates Serine sites of ER $\alpha$ [57]. The induced expression of miR-873 inhibited the ER $\alpha$ transcriptional activity in MCF7/Tam R cells and sensitized these cells to tamoxifen. Additionally, the injection of cells expressing miR-873 into nude mice treated with tamoxifen inhibited the tumor growth by increasing the sensitivity to tamoxifen in vivo [57].

Some microRNAs may target ER isoforms and modulate Tam resistance. ER- $\alpha 36$, upregulated in resistant cells, is a target of let-7 and induced let-7 expression in Tamresistant MCF7 cells, downregulated ER- $\alpha 36$ expression and enhanced the sensitivity of MCF7 cells [95]. Additionally, the CUL4B protein influences Tam-resistance of breast cancer cells by upregulating ER- $\alpha 36$ expression, which was mediated by downregulation of miR32-5p [96]. A larger number of miRNAs have been found to regulate ESR1 expression but without reported roles in tamoxifen response have not been included in this review.

Another important protein regulated by miRs acting as mediator of tamoxifen resistance is ERBB2/ HER2 [97-99]. Reduced expression of miR-26a/b, which can regulate $E R B B 2$ levels post-transcriptionally through interaction with its $3^{\prime} \mathrm{UTR}$, correlates with ERBB2 upregulation in MCF7/TAMR and T47D/TAMR cells, derived by long-term exposure to tamoxifen [40].

PTEN (phosphatase and tensin homolog) acts as a tumor suppressor and is an important negative regulator of the PI3K signaling pathway. Alterations in PTEN occur frequently in breast cancer cells and promote cell growth, survival, and migration [100]. Some miRs such as miR-29a/b, miR-146b, miR-301, and miR-519a have PTEN as a target and thus might influence tamoxifen therapy outcomes [101-104]. MCF-7 tamoxifen-resistant 
cells can express high levels of miRNA-519a, which directly represses the expression of PTEN and induces cell proliferation [102]. Higher levels of miR-221/222 also downregulate PTEN. On the other hand, some miRs have reduced levels in Tam resistant cells. Phuong and colleagues [103] studied miR-146a/b expression levels in tamoxifen-resistant MCF7 derived by long-term exposure. They observed that miR-146b can restore PTEN expression by suppressing PTEN promoter methylation in resistant cells. Furthermore, miR-146b overexpression inhibited cell proliferation and restored tamoxifen-sensibility in MCF7/TAMR [103].

Finally, some authors found that miRs could target histone deacetylases (HDACs). Although the role of these molecules in the induction of hormone therapy resistance in breast cancer cells remains uncertain, HDACs dysregulation stimulates cancer cell survival [105]. Studies demonstrated that miR-10b and miR-125a are associated with HDAC4/HDAC2 and HDAC5 expression, respectively [56,105]. These miRNAs seem to influence invasion, migration, and metastasis, in addition to drug resistance of breast cancer cells. Ahmad and colleagues [56] observed that overexpression of miR-10b, in ER+ cells increases resistance to tamoxifen and there is a negative correlation between HDAC4 and miR-10b expression. Downregulation of HDAC4 is induced by miR-10b, and the authors propose miR-10b-HDAC4 as a molecular mechanism related to tamoxifen resistance.

Huang and colleagues also reported that resistant MCF7-TamC3 (created by prolonged culture under estrogen-deprived conditions) demonstrated decreased expression of miR-125a-5p, but increased expression of HDAC2 and HDAC5 compared to the parental tamoxifen-sensitive cells [105]. These outcomes suggest that dysregulations of $H D A C 2$, $H D A C 4$, and HDAC5 can collaborate with the development of tamoxifen resistance in $\mathrm{ER}+$ breast cancer cells associated with miR-10b and miR-125a-5p deregulation.

Downregulation of the tumor suppressor miR-125a-5p was correlated with poor relapse-free survival (RFS) in tamoxifen-treated BC patients [105]. Induced expression of miR-125a-5p and also of miR-27b-3p, miR-29b-1, miR-135a, miR-500a-3p, miR-186-3p, miR-320a, and miR-4653-3p in breast cancer cell lines restored the sensitivity to tamoxifen, suggesting that these miRs are important as potential therapeutic options [89,105-110].

Using in vivo models, He and colleagues reported that restoration of miR-186-3p by systemic delivery of cholesterol-modified agomiR-186-3p to mice with T47D-tamoxifen $\mathrm{R}$ cells implantation suppressed tumor growth. Its role in the tamoxifen response and cell metabolism in ER+ breast cancer cells is promoted by the miR-186-3p/EREG/EGFR axis [110]. Likewise, the induced expression of miR-320a in MCF7-Tam R cells implanted in nude mice treated with tamoxifen inhibited tumor growth by restoring tamoxifen sensitivity [106]. The transference of exosomal miRNAs to cancer cells has also been studied. Liu and colleagues showed that injection of exosomes derived from MCF-7/TAM resistant cells transfected with miR-9-5p inhibitor into nude mice reduced the tumor volume and increased cell apoptosis [111,112].

Several other microRNAs with different target genes were also reported to play a role in tamoxifen resistance, as shown in Table 1.

Table 1. microRNAs associated with tamoxifen-resistance.

\begin{tabular}{ccc}
\hline microRNA & Targets & Reference \\
\hline Upregulated & & {$[111,112]$} \\
miR-9-5p & ADIPOQ, ESR1, NCOA3 & {$[56]$} \\
miR-10b & HDAC4 & {$[113]$} \\
miR-15b & FOXO1 & {$[114]$} \\
miR-18a & $E S R 1$ & {$[86,115-117]$} \\
miR-21 & PDCD4,TPM1 & {$[118]$} \\
miR-22 & ESR1, PTEN & {$[119,120]$} \\
miR-23b-3p & SLC6A14, ZBTB1 & {$[84]$} \\
\hline
\end{tabular}


Table 1. Cont.

\begin{tabular}{|c|c|c|}
\hline microRNA & Targets & Reference \\
\hline miR-92a-3p & $\begin{array}{l}\text { C21orf91, GPM6A, KAT2B, NEDD4L, UBE2Z, } \\
\text { ROBO2, PCDH11X, PDS5B, TMEM87A, PRKCE }\end{array}$ & [121] \\
\hline miR-101 & MAGI-2 & [122] \\
\hline miR-140 & - & [122] \\
\hline miR-155 & SOCS6 & [123] \\
\hline miR-181 & - & [86] \\
\hline miR-192-5p & ESR1 & [89] \\
\hline $\mathrm{miR}-221 / 222$ & P27, ESR1, TRPS1 & {$[86-88,93]$} \\
\hline miR-301 & PTEN, FOXF2, COL2A1, BBC3 & [101] \\
\hline miR-335-3p; miR-335-5p & ESR1 & [90] \\
\hline miR-342 & - & [124] \\
\hline miR-342-3p; miR-342-5p & $\begin{array}{c}\text { NR4A2, MAGED2, LASP1, UCP2, THSD4, } \\
\text { PRODH, PIP4KSC, MEIS1, BMP7, PRR6, } \\
\text { GEMIN4, GJAI, SEMA3D }\end{array}$ & {$[117,124]$} \\
\hline miR-335-5p, miR-335-3p & ESR1 & [90] \\
\hline miR-380 & - & [122] \\
\hline miR-489 & - & [86] \\
\hline miR-497 & - & [125] \\
\hline miR-519a & CDKN1A, RB1, PTEN & {$[102,125]$} \\
\hline miR-542-5p & YWHAB, LY9, SFRP1 & [126] \\
\hline miR-552 & - & [122] \\
\hline $\operatorname{miR}-575$ & $C D K N 1 B$ & [127] \\
\hline miR-578 & - & [122] \\
\hline miR-599 & - & [122] \\
\hline $\operatorname{miR}-663 b$ & TP73 & [128] \\
\hline miR-671-3p & HNRNPA2B1 & [129] \\
\hline $\operatorname{miR}-1266-5 p$ & HNRNPA2B1 & [129] \\
\hline miR-1268a & HNRNPA2B1 & [129] \\
\hline $\operatorname{miR}-1280$ & - & [125] \\
\hline \multicolumn{3}{|l|}{ Downregulated } \\
\hline let-7 & ESR1 (ER- $\alpha 36$ isoform) & [130] \\
\hline $\operatorname{miR}-15 a$ & BCL2, CCNE1 & {$[124,131]$} \\
\hline $\operatorname{miR}-16$ & $B C L 2, C C N E 1$ & {$[124,131]$} \\
\hline $\operatorname{miR}-21$ & PTEN, PDCD4 & {$[132]$} \\
\hline miR-26a & $E 2 F 7, E Z H 2, E R B B 22 H 1$ & {$[40]$} \\
\hline miR-27a;miR-27b-3p & HMGB3, NR5A2, CREB1 & {$[59,107,133]$} \\
\hline miR-29a;miR-29b-1 & DICER1, PTEN & [104] \\
\hline miR-29a-3p; miR-29b-3p & HNRNPA2B1, ATP5G1, ATPIF1 & {$[104,129]$} \\
\hline miR-32-5p & CUL4B & [96] \\
\hline miR-101 & - & [125] \\
\hline miR-106a & CDKN1A, PTEN, RB1 & [125] \\
\hline $\operatorname{miR}-125 a$ & CYP4Z1, CYP4Z2P, CDK3, HER2, HER3 & {$[108,134]$} \\
\hline miR-125a-3p; miR-125a-5p & HDAC5 & {$[105,109]$} \\
\hline miR-125b-5p & PAD2 & [135] \\
\hline miR-135a & ESR1, ESRRA, NCOA1 & [94] \\
\hline miR-146a; miR-146b & NFKB1, PI3K, TRAF6, IRAK1, PTEN & {$[103,117]$} \\
\hline miR-148a & ALCAM & [60] \\
\hline miR-152 & $A L C A M$ & {$[60]$} \\
\hline miR-181 & - & [125] \\
\hline miR-186-3p & EREG & [110] \\
\hline $\mathrm{miR}-193 \mathrm{a} / \mathrm{b}-3 \mathrm{p}$ & ESR1, NCOA3 & [112] \\
\hline miR-196a & HOXB7 & [136] \\
\hline $\mathrm{miR}-200$ & $Z E B 1 / 2$ & [137] \\
\hline miR-214 & UCP2 & [58] \\
\hline
\end{tabular}


Table 1. Cont.

\begin{tabular}{ccc}
\hline microRNA & Targets & Reference \\
\hline miR-222-3p & ESR1, CDKN1B, HNRNPA2B1 & {$[129]$} \\
miR-320a & ARPP19, ESRRG & {$[106]$} \\
miR-342 & TXNIP, SEMAD, BMP7, GEMIN4 & {$[138]$} \\
miR-363 & SERTAD3 & {$[139]$} \\
miR-375 & HOXB3, MTDH & {$[102,140]$} \\
miR-378a-3p & GOLT1A & {$[141]$} \\
miR-449a & ADAM22 & {$[142]$} \\
miR-451 & $14-3-3 \zeta$ & {$[143,144]$} \\
miR-484 & KLF4 & {$[145]$} \\
miR-500a-3p & LY6K & {$[134]$} \\
miR-574-3p & $C L T C$ & {$[57,146]$} \\
miR-873 & CDK3 & {$[134]$} \\
miR-877 & - & {$[108]$}
\end{tabular}

Note: Regulation (up or down) of miRNAs in tamoxifen resistant breast cancer cells is indicated as reported. (-) information not provided in the study.

\subsection{Long Non-Coding RNAs and Tamoxifen Resistance}

Growing evidence suggests a role for some lncRNAs in endocrine therapy resistance for estrogen receptor-positive breast cancer. Regarding tamoxifen specifically, most of the studied lncRNAs that have been associated with the resistance process are upregulated. The expression of IncRNA LINC-ROR (ROR, regulator of reprogramming), for example, is positively associated with tamoxifen resistance $[42,147,148]$. LINC-ROR knockdown through in vitro and in vivo experiments indicated that this lncRNA may also contribute to cancer progression, since its inhibition reduces cell proliferation, invasion and migration [148], while LINC-ROR knockout enhanced breast cancer cell sensitivity to tamoxifen [147].

The mechanisms by which LINC-ROR might promote Tam resistance are not fully elucidated, but they might be related to inhibition of autophagy, since upregulation of LINC-ROR is negatively associated with MAP1LC3A (coding for LC3) and BECN1 (coding for Beclin I) expression [148]. LINC-ROR may also be involved in estrogen receptor activation through the MAPK/ERK pathway, specifically by facilitating the degradation of the ERK-phosphatase DUSP7 [147]. In addition, LINC-ROR knockdown and overexpression experiments demonstrated that it might have an important role in EMT by acting as a sponge to miR-205-5p and, in consequence, positively regulating the ZEB1 and ZEB2 transcription factors [33]. Combined siLINC-ROR and tamoxifen treatment inhibited the tumor growth and metastasis of BT474 cells in nude mice [148].

H19 is one of the most studied lncRNAs in breast cancer, and its upregulation in tamoxifen resistance has been explored in multiple studies $[85,149,150]$. In resistant cells, H19 silencing increased the sensitivity to tamoxifen $[85,149,150]$, observed by a decrease in cell proliferation [150], invasion ability [150], cell survival [149,150] and an increased in apoptosis [150]. In addition, H19 downregulation inhibited the Wnt/ $\beta$-catenin pathway and EMT process [150]. Other processes are highlighted in H19-mediated resistance response. Unlike what has been described for ROR, the H19 lncRNA exhibits a positive correlation with Beclin-1 and LC3-II expression, and a strong induction of the autophagy process in resistant cells [85]. Autophagy exhibits dual roles in cancer development. This mechanism is involved in cell protection to clear damaged organelles and remove products of metabolism. However, this process also takes part in cancer cell chemotherapy resistance as a protective mechanism to survival [151-153]. H19 appears to regulate autophagy through the H19-SAHH-DNMT3B axis that promotes Beclin-1 promoter methylation [85]. In another mechanism, Tam resistance is reversed by the downregulation of $\mathrm{H} 19$ through the inhibition of the Notch and c-Met signaling pathway. The development of resistance to tamoxifen in endocrine therapy-resistant cells can also be related to H19-mediated regulation of ER $\alpha$ expression [149]. 
Another highlighted lncRNA is the urothelial carcinoma-associated 1 (UCA1) transcript, which may also enhance tamoxifen resistance [154-158] and is correlated with breast cancers outcome [155]. Interestingly, Tam treatment itself, through HIF1A upregulation, might enhance UCA1 expression, which in turn seems to increase tamoxifen resistance [154]. There might be a regulatory feedback loop concerning UCA1, since it may act as a sponge for miR-18a, which is a negative regulator of HIF1A [154]. Furthermore, UCA1 is positively associated with cell viability [154,157], cell survival cell colony formation [154], migration [155], and cell cycle progression [154,159], while it is negatively related to cell apoptosis [154-157]. LncRNA UCA1 may activate the PI3K/AKT pathway by inducing cell cycle progression through the phosphorylation of CREB through AKT [159] and preventing apoptosis through the activation of mTOR [156]. In addition, another suggested mechanism by which lncRNA UCA1 may promote tamoxifen resistance involves the nuclear translocation of $\beta$-catenin in the Wnt/ $\beta$-catenin pathway [155].

Upregulation of CCAT2 (colon cancer-associated transcript 2) lncRNA was observed in breast cancer tissues and cell lines, besides being associated with poor prognosis $[160,161]$. In addition, tamoxifen-resistant cells also exhibited higher CCAT2 expression [162]. This IncRNA may be related to tamoxifen resistance by hyper-activating the ERK / MAPK pathway. CCAT2 knockdown experiments showed decreased cell proliferation, increased apoptosis rates, and improved sensitivity to tamoxifen [162].

DSCAM-AS1 (down syndrome cell adhesion molecule-antisense RNA 1) is a lncRNA whose gene contains estrogen response elements [163]. Its expression is induced in the response to estrogens and reversed with tamoxifen treatment [155]. DSCAM-AS1 is upregulated in breast cancer tissues and in tamoxifen resistant cells and positively associated with high grade and metastasis [164]. Additionally, silencing experiments decreased cell proliferation [164,165], increased apoptosis rate, and induced cell cycle arrest at G0 / G1 [165]. The RNA binding-protein hnRNPL interacts with DSCAM-AS1 3'-end and its knockdown also reduced cell proliferation in resistant cells. Thus, hnRNPL participates with DSCAM-AS1 in tamoxifen-resistance response [164]. There is no consensus regarding how DSCAM-AS1 promotes resistance in ER-positive breast cancers under tamoxifen treatment. One of the mechanisms involves regulating the epidermal growth factor receptor pathway substrate 8 (EPS8) gene [165], since EPS8 silencing has the same effects as suppressing DSCAM-AS1. In this regulatory way, DSCAM-AS1 sponges miR-137, precluding EPS8 regulation [165].

Overexpression of HOTAIR has been observed in Tam resistant breast tumors when compared to primary ones, and its downregulation significantly suppressed growth in Tam resistant model cell lines, suggesting it may represent a therapeutic target for Tam-resistant tumors. HOTAIR is directly repressed at the transcriptional level by estrogen-activated ER and is overexpressed in estrogen-depleted or tamoxifen-treated cells. HOTAIR can interact with ER $\alpha$ to increase its genomic signaling by increasing ER $\alpha$ protein levels. The effects were more prominent in the absence of ligand, suggesting a role of HOTAIR in regulating ligand-independent ER signaling $[166,167]$. In addition, HOTAIR has also been reported to interact with the histone modifying complexes polycomb repressive complex 2 (PRC2) and LSD1/COREST/REST, which may silence tumor suppressor genes such as PTEN, making HOTAIR a potential broad therapeutic target [168-170]. Another IncRNA negatively regulated by ER signaling is LINP1, whose knockdown increased the tamoxifen sensitivity in vivo [171].

Recently, the lncRNAs BDNF-AS [172], MAFG-AS1 [173] and DILA 1 [174] were also associated with Tam resistance. BDNF-AS overexpression promotes Tam resistance through the BDNF-AS/RNH1/TRIM21/mTOR pathway [172]. The MAFG-AS1 is upregulated in BC samples [173,175-177] and luminal subtype patients [173]. The MAFG-AS1 knockdown in luminal cell lines, MCF-7 and T47D, decreased cell proliferation, colony formation and promoted cell cycle arrest at G1. MAFG-AS1 is related to cell proliferation due to its function as competing endogenous RNA (ceRNA) of miR-339-5p which regulates CDK2 expression [173]. The knockdown of MAFG-AS1 and CDK2 decreased the proliferative capacity of MCF7 resistant-cells cultivated with tamoxifen. Thus, MAFG-AS1 and CDK2 
promoted tamoxifen resistance. The knockdown of the ESR1 gene in T47D cells upon E2 treatment revealed that MAFG-AS1 expression is regulated by ER $\alpha$, within binds to the MAFG-AS1 promoter. The oncogenic role of MAFG-AS1 in the luminal subtype is dependent of the ER $\alpha$ transcription factor [173].

The novel lncRNA DILA1 (cyclin-D1 interacting long noncoding RNA 1) was identified as a regulator of cyclin D1 levels in MCF7 and T47D tamoxifen-resistant cells [174]. DILA1 knockdown decreased cell growth, arrested the cell cycle at G1/S and reversed tamoxifen resistance. In addition, DILA1 higher expression was associated with the clinical stage and with lymph node metastasis [174].

On the other hand, some lncRNAs such as ADAMTS9-AS2 and GAS5 seem to promote Tam resistance only when downregulated. Both of them act as sponges of miR-130a-5p and miR-222, respectively $[178,179]$. These miRNAs are negative regulators of PTEN expression. PTEN acts by blocking the PI3K/AKT signaling pathway and thus inhibiting AKT-mediated oncogenic signaling [180]. Downregulation of PTEN was previously related to tamoxifen-resistance in the MCF-7 breast cancer cell line overexpressing the tumor suppressor gene $M T D H$ [181].

ADAMTS9-AS2 (ADAMTS9 antisense RNA 2) was described in chemoresistance in some types of cancer, including renal and glioblastoma [182,183], besides breast cancer. In Tam-resistant breast cancer tissues and cell lines, ADAMTS9-AS2 is downregulated [178]. ADAMTS9-AS2 overexpression decreased the viability of MCF7-R cells and increased apoptosis. The expression levels of this lncRNA and of the PTEN tumor suppressor gene are positively correlated in breast cancer cells. Furthermore, ADAMTS9-AS2 may act as a sponge of miRNA-130a-5p in this regulatory network [178].

GAS5 (growth arrest-specific transcript 5) is another lncRNA that exhibits a positive correlation with PTEN expression in tamoxifen-resistant cells [179]. The low expression of GAS5 is related to the increase in cell proliferation and the invasion ability and a decrease in apoptosis. On the other hand, GAS5 upregulation allows tamoxifen sensitivity by acting as a sponge for miR-222 [179]. In vivo experiments with MCF7-R cells treated with tamoxifen and transfected with a vector overexpressing a GAS5 cDNA into nude mice decreased tumor growth [179]. This effect highlights the potential of GAS5 upregulation in restoring tamoxifen sensitivity.

Other lncRNAs described in tamoxifen resistance are summarized in Table 2.

Table 2. LncRNAs associated with tamoxifen resistance.

\begin{tabular}{|c|c|c|c|}
\hline $\operatorname{lncRNA}$ & Ensembl Gene ID & Mechanism/Pathway & Reference \\
\hline \multicolumn{4}{|l|}{ Upregulated } \\
\hline ATXN8OS & ENSG00000230223 & miR-16-5p/VASP regulation & [184] \\
\hline BDNF-AS & ENSG00000245573 & RNH1/TRIM21/mTOR pathway & [172] \\
\hline BLACAT1 & ENSG00000281406 & miR-503/Bcl-2 regulation & [185] \\
\hline CCAT2 & ENSG00000280997 & Hyperactivation of ERK/MAPK pathway & [162] \\
\hline CYTOR & ENSG00000222041 & miR-125a-5p/SRF regulation & [127] \\
\hline DILA1 & ENST00000435697.1 & cyclin D1 binding/pRb phosphorylation & {$[174]$} \\
\hline \multirow[t]{2}{*}{ DSCAM-AS1 } & ENSG00000235123 & Interaction with hnRNPL & [164] \\
\hline & & miR-137/EPS8 regulation & [165] \\
\hline FAM83H-AS1 & ENSG00000203499 & - & [186] \\
\hline \multirow[t]{3}{*}{ H19 } & ENSG00000130600 & Wnt/ $\beta$-catenin pathway and EMT process & [150] \\
\hline & & Induction of autophagy & {$[85]$} \\
\hline & & Notch and c-Met signaling, ESR1 regulation & [149] \\
\hline HNF1-AS1 & ENSG00000241388 & $\begin{array}{c}\text { miR-363/SERTAD3 regulation/TGF-B/Smad } \\
\text { pathway regulation }\end{array}$ & [139] \\
\hline HOTAIR & ENSG00000228630 & Promotion of ligand-independent ER activation & [166] \\
\hline
\end{tabular}


Table 2. Cont.

\begin{tabular}{|c|c|c|c|}
\hline $\operatorname{lncRNA}$ & Ensembl Gene ID & Mechanism/Pathway & Reference \\
\hline HOTAIRM1 & ENSG00000233429 & Upregulation of HOXA1 & [187] \\
\hline \multirow[t]{3}{*}{ LINC-ROR } & ENSG00000258609 & Inhibition of autophagy & [148] \\
\hline & & MAPK/ERK pathway & [147] \\
\hline & & Epithelial-mesenchymal transition & [33] \\
\hline LINP1 & ENSG00000223784 & Reduces ESR1 expression & [171] \\
\hline LOL & ENST00000456526 & let-7 inhibition & [188] \\
\hline MAFG-AS1 & ENSG00000265688 & miR-339-5p/CDK2 regulation & [173] \\
\hline TMPO-AS1 & ENSG00000257167 & stabilizes ESR1 mRNA/ESR1 regulation & [189] \\
\hline \multirow[t]{5}{*}{ UCA1 } & ENSG00000214049 & mTOR pathway & [156] \\
\hline & & Feedback loop with miR-18a/HIF1A & [157] \\
\hline & & Wnt $/ \beta$-catenin pathway & [155] \\
\hline & & PI3K/AKT pathway & [159] \\
\hline & & - & [157] \\
\hline \multicolumn{4}{|l|}{ Downregulated } \\
\hline $\begin{array}{c}\text { ADAMTS9- } \\
\text { AS2 }\end{array}$ & ENSG00000241684 & miR-130a-5p/PTEN regulation & [178] \\
\hline GAS5 & ENSG00000234741 & miR-222/PTEN regulation & [179] \\
\hline LINC00472 & ENSG00000233237 & $\mathrm{ER} \alpha$-inducible/NF-KB regulation & [190] \\
\hline LINC00894-002 & ENST00000444489 & TGF- $\beta 2$ pathway & [191] \\
\hline
\end{tabular}

Note: Regultion (up or down) of lncRNAs in tamoxifen resistant breast cancer cells is indicated as reported. (-) information not provided in the study.

\section{Final Considerations}

In this literature review, we identified 75 microRNAs and 22 lncRNAs associated with Tam resistance. The mechanisms of Tam resistance are complex and include multiple actors involved in different functions and signaling pathways. The ncRNAs participate in important regulatory processes and evidence thus far indicates that they can contribute to Tam resistance (Figure 4).

These ncRNAs can have multiple targets that are able to participate in more than one regulatory pathway. Their action may be modulated by the relative expression levels of their different targets in the cancer cell. In addition, microRNAs and IncRNAs may crosstalk by targeting overlapping sets of genes and jointly contributing to the regulation of the signaling pathways involved in tamoxifen resistance. Furthermore, lncRNAs can act as sponges for miRNAs, dampening their action on target transcripts. These interactions are thus complex and the better we identify potential regulators and clarify their mechanisms of action, the better we will understand their impact on the resistance process.

Use of genomic testing in early-stage hormone receptor-positive breast cancer to aid the therapeutic choice has become a reality in the clinic, but ncRNAs are underexploited in this respect. The increasing volume of information about the pertinence of ncRNAs, mainly microRNAs, suggests that these molecules should be further studied for inclusion in future panels. These panels can, in addition to contributing to a more incisive diagnosis, guide the best treatment through predictions of the therapeutic response for each patient. The stability of miRNAs in blood [192] may also facilitate detection of emergent resistant tumor subclones during treatment.

As for the use of ncRNAs in therapeutic strategies, direct applications to patient care are even further away. However, initial successes of RNA interference strategies are promising in this respect, including miRNA mimics and inhibitors (antimiRs) [193]. From the great number of studies identifying miRNAs as potential therapeutic targets, some have led to clinical trials. For example, a mimic of miR-34 is in phase I clinical trials for cancer treatment and antimiRs for miR- 122 have reached phase II trials for treating hepatitis [194,195]. This information gives hope for the clinical usefulness of ncRNA modulators that may interfere in tamoxifen resistance. 


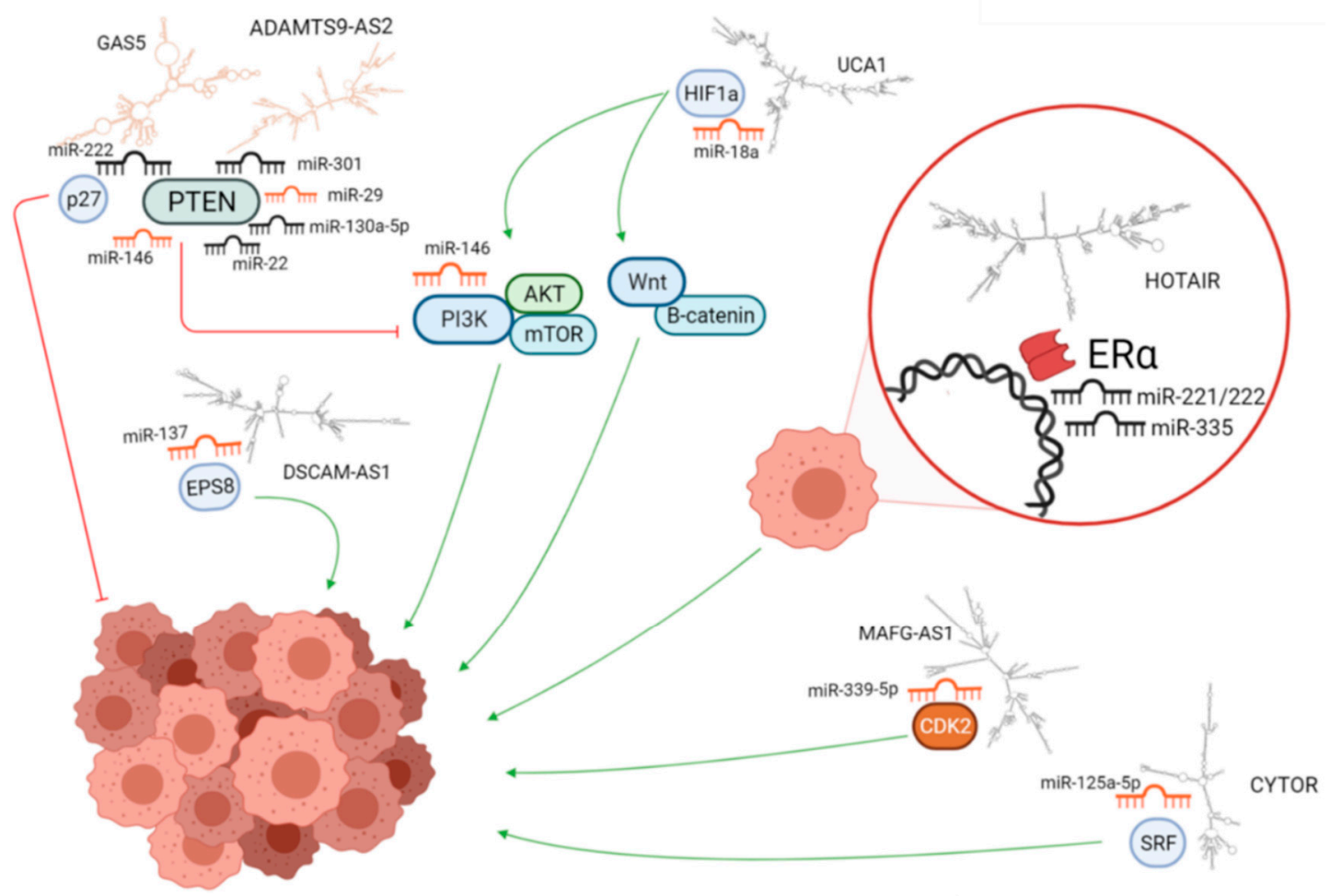

Figure 4. miRNAs, lncRNAs, and target mRNA differentially expressed in resistant breast cancer cells lines. Upregulated miRNAs and lncRNAs are in black, while those downregulated are in orange. Structures of lncRNAs were predicted using the RNAfold tool in the ViennaRNA Package 2.0 and drawn using MFE plain structure drawing. The figure does not contain all regulatory molecules found in this study. The molecules are not to scale.

In conclusion, knowledge about the roles of ncRNAs in Tam resistance may help to elucidate this serious problem that influences the treatment and prognosis of thousands of patients. Additionally, this knowledge can be used to improve biomarker panels for molecular diagnosis and treatment prediction, in order to individualize the therapeutic approach and give the patient more accurate treatment, for example, identifying patients at greater risk of relapse due to the expression patterns of non-coding RNAs that impact the response to Tam. Additionally, this knowledge may, in the future, be used to improve treatment options and possibly also to design therapeutic strategies to bypass mechanisms of resistance.

Author Contributions: J.C.d.O. and S.M. designed this study. J.F.B., T.S.J., T.M.C., R.N.V., A.F.K., D.F.G., J.B. and H.A.B. performed analysis and wrote the manuscript. J.C.d.O. and S.M. reviewed analysis and interpretation and wrote the manuscript. All authors have read and agreed to the published version of the manuscript.

Funding: This research was funded by This research was funded by CNPq and CAPES (001 and CAPES/PRINT grant number 88887.194815/2018-00) to J.C.d.O. and by CIHR grant \# PJT 153178 and 156199 to S.M.

Conflicts of Interest: The authors declare no conflict of interest.

\section{References}

1. Sung, H.; Ferlay, J.; Siegel, R.L.; Laversanne, M.; Soerjomataram, I.; Jemal, A.; Bray, F. Global Cancer Statistics 2020: GLOBOCAN Estimates of Incidence and Mortality Worldwide for 36 Cancers in 185 Countries. CA Cancer J. Clin. 2021, 71, 209-249. [CrossRef]

2. Eroles, P.; Bosch, A.; Pérez-Fidalgo, J.A.; Lluch, A. Molecular biology in breast cancer: Intrinsic subtypes and signaling pathways. Cancer Treat. Rev. 2012, 38, 698-707. [CrossRef] [PubMed]

3. American Cancer Society. Breast Cancer Facts E Figures 2019-2020; American Cancer Society: Atlanta, GA, USA, 2019.

4. Harbeck, N.; Gnant, M. Breast cancer. Lancet 2017, 389, 1134-1150. [CrossRef] 
5. Traboulsi, T.; El Ezzy, M.; Gleason, J.; Mader, S. Antiestrogens: Structure-activity relationships and use in breast cancer treatment. J. Mol. Endocrinol. 2017, 58, R15-R31. [CrossRef] [PubMed]

6. Abe, O.; Abe, R.; Enomoto, K.; Kikuchi, K.; Koyama, H.; Masuda, H.; Nomura, Y.; Sakai, K.; Sugimachi, K.; Tominaga, T.; et al. Effects of chemotherapy and hormonal therapy for early breast cancer on recurrence and 15-year survival: An overview of the randomised trials. Lancet 2005, 365, 1687-1717. [CrossRef]

7. Pan, H.; Gray, R.; Braybrooke, J.; Davies, C.; Taylor, C.; McGale, P.; Peto, R.; Pritchard, K.I.; Bergh, J.; Dowsett, M.; et al. 20-Year Risks of Breast-Cancer Recurrence after Stopping Endocrine Therapy at 5 Years. N. Engl. J. Med. 2017, 377, 1836-1846. [CrossRef] [PubMed]

8. Ring, A.; Dowsett, M. Mechanisms of tamoxifen resistance. Endocr. Relat. Cancer 2004, 11, 643-658. [CrossRef]

9. Kangaspeska, S.; Hultsch, S.; Jaiswal, A.; Edgren, H.; Mpindi, J.-P.; Eldfors, S.; Brück, O.; Aittokallio, T.; Kallioniemi, O. Systematic drug screening reveals specific vulnerabilities and co-resistance patterns in endocrine-resistant breast cancer. BMC Cancer 2016, 16, 378. [CrossRef]

10. Hultsch, S.; Kankainen, M.; Paavolainen, L.; Kovanen, R.-M.; Ikonen, E.; Kangaspeska, S.; Pietiäinen, V.; Kallioniemi, O. Association of tamoxifen resistance and lipid reprogramming in breast cancer. BMC Cancer 2018, 18, 1-14. [CrossRef] [PubMed]

11. Radhi, S. Molecular Changes During Breast Cancer and Mechanisms of Endocrine Therapy Resistance. Prog. Mol. Biol. Transl. Sci. 2016, 144, 539-562. [CrossRef]

12. Sanchez, R.; Nguyen, D.; Rocha, W.; White, J.H.; Mader, S. Diversity in the mechanisms of gene regulation by estrogen receptors. BioEssays 2002, 24, 244-254. [CrossRef]

13. Cotnoir-White, D.; Laperrière, D.; Mader, S. Evolution of the repertoire of nuclear receptor binding sites in genomes. Mol. Cell. Endocrinol. 2011, 334, 76-82. [CrossRef] [PubMed]

14. Brufsky, A.M.; Dickler, M.N. Estrogen Receptor-Positive Breast Cancer: Exploiting Signaling Pathways Implicated in Endocrine Resistance. Oncologist 2018, 23, 528-539. [CrossRef] [PubMed]

15. Begam, A.J.; Jubie, S.; Nanjan, M. Estrogen receptor agonists/antagonists in breast cancer therapy: A critical review. Bioorg. Chem. 2017, 71, 257-274. [CrossRef]

16. Stender, J.D.; Frasor, J.; Komm, B.; Chang, K.C.N.; Kraus, W.L.; Katzenellenbogen, B.S. Estrogen-Regulated Gene Networks in Human Breast Cancer Cells: Involvement of E2F1 in the Regulation of Cell Proliferation. Mol. Endocrinol. 2007, 21, 2112-2123. [CrossRef] [PubMed]

17. Bourdeau, V.; Deschênes, J.; Laperrière, D.; Aid, M.; White, J.; Mader, S. Mechanisms of primary and secondary estrogen target gene regulation in breast cancer cells. Nucleic Acids Res. 2007, 36, 76-93. [CrossRef]

18. Glück, S. Consequences of the Convergence of Multiple Alternate Pathways on the Estrogen Receptor in the Treatment of Metastatic Breast Cancer. Clin. Breast Cancer 2017, 17, 79-90. [CrossRef]

19. Wang, Z.-Y.; Yin, L. Estrogen receptor alpha-36 (ER- $\alpha 36)$ : A new player in human breast cancer. Mol. Cell. Endocrinol. 2015, 418, 193-206. [CrossRef]

20. Penot, G.; Le Péron, C.; Mérot, Y.; Grimaud-Fanouillère, E.; Ferriere, F.; Boujrad, N.; Kah, O.; Saligaut, C.; Ducouret, B.; Métivier, R.; et al. The Human Estrogen Receptor- $\alpha$ Isoform hER $\alpha 46$ Antagonizes the Proliferative Influence of hER $\alpha 66$ in MCF7 Breast Cancer Cells. Endocrinology 2005, 146, 5474-5484. [CrossRef]

21. Maczis, M.A.; Maceyka, M.; Waters, M.R.; Newton, J.; Singh, M.; Rigsby, M.F.; Turner, T.; Alzubi, M.A.; Harrell, J.C.; Milstien, S.; et al. Sphingosine kinase 1 activation by estrogen receptor $\alpha 36$ contributes to tamoxifen resistance in breast cancer. J. Lipid Res. 2018, 59, 2297-2307. [CrossRef] [PubMed]

22. Zhang, X.; Cao, J.; Wang, Z. ER- $\alpha 46$, a variant of ER- $\alpha$, is expressed in human breast carcinoma and enhances estrogen sensitivity in breast cancer cells. Cancer Res. 2007, 67, 986.

23. Reinert, T.; Saad, E.D.; Barrios, C.H.; Bines, J. Clinical Implications of ESR1 Mutations in Hormone Receptor-Positive Advanced Breast Cancer. Front. Oncol. 2017, 7. [CrossRef]

24. Katzenellenbogen, J.A.; Mayne, C.G.; Katzenellenbogen, B.S.; Greene, G.L.; Chandarlapaty, S. Structural underpinnings of oestrogen receptor mutations in endocrine therapy resistance. Nat. Rev. Cancer 2018, 18, 377-388. [CrossRef]

25. Rondón-Lagos, M.; Villegas, V.E.; Rangel, N.; Sánchez, M.C.; Zaphiropoulos, P.G. Tamoxifen resistance: Emerging molecular targets. Int. J. Mol. Sci. 2016, 17, 1357. [CrossRef]

26. Venditti, M.; Iwasiow, B.; Orr, F.W.; Shiu, R.P. C-myc gene expression alone is sufficient to confer resistance to antiestrogen in human breast cancer cells. Int. J. Cancer 2002, 99, 35-42. [CrossRef] [PubMed]

27. Wilcken, N.R.; Prall, O.W.; Musgrove, E.A.; Sutherland, R.L. Inducible overexpression of cyclin D1 in breast cancer cells reverses the growth-inhibitory effects of antiestrogens. Clin. Cancer Res. 1997, 3, 849-854. [PubMed]

28. Stendahl, M.; Kronblad, Å.; Rydén, L.; Emdin, S.; Bengtsson, N.O.; Landberg, G. Cyclin D1 overexpression is a negative predictive factor for tamoxifen response in postmenopausal breast cancer patients. Br. J. Cancer 2004, 90, 1942-1948. [CrossRef]

29. Ishii, Y.; Waxman, S.; Germain, D. Tamoxifen Stimulates the Growth of Cyclin D1-Overexpressing Breast Cancer Cells by Promoting the Activation of Signal Transducer and Activator of Transcription. Cancer Res. 2008, 68, 852-860. [CrossRef] [PubMed]

30. Lundgren, K.; Brown, M.; Pineda, S.; Cuzick, J.; Salter, J.; Zabaglo, L.; Howell, A.; Dowsett, M.; Landberg, G. Effects of cyclin D1 gene amplification and protein expression on time to recurrence in postmenopausal breast cancer patients treated with anastrozole or tamoxifen: A TransATAC study. Breast Cancer Res. 2012, 14, R57. [CrossRef] 
31. Gu, W.; Dong, N.; Wang, P.; Shi, C.; Yang, J.; Wang, J. Tamoxifen resistance and metastasis of human breast cancer cells were mediated by the membrane-associated estrogen receptor ER- $\alpha 36$ signaling in vitro. Cell Biol. Toxicol. 2016, 33, 183-195. [CrossRef] [PubMed]

32. Garcia-Martinez, L.; Zhang, Y.; Nakata, Y.; Chan, H.L.; Morey, L. Epigenetic mechanisms in breast cancer therapy and resistance. Nat. Commun. 2021, 12, 1-14. [CrossRef]

33. Zhang, H.-Y.; Liang, F.; Zhang, J.-W.; Wang, F.; Wang, L.; Kang, X.-G. Effects of long noncoding RNA-ROR on tamoxifen resistance of breast cancer cells by regulating microRNA. Cancer Chemother. Pharmacol. 2017, 79, 327-337. [CrossRef]

34. Hull, E.E.; Montgomery, M.; Leyva, K.J. HDAC Inhibitors as Epigenetic Regulators of the Immune System: Impacts on Cancer Therapy and Inflammatory Diseases. BioMed. Res. Int. 2016, 2016, 1-15. [CrossRef] [PubMed]

35. Kawai, H.; Li, H.; Avraham, S.; Jiang, S.; Avraham, H. Overexpression of histone deacetylase HDAC1 modulates breast cancer progression by negative regulation of estrogen receptor? Int. J. Cancer 2003, 107, 353-358. [CrossRef]

36. Thomas, S.; Munster, P.N. Histone deacetylase inhibitor induced modulation of anti-estrogen therapy. Cancer Lett. 2009, 280, 184-191. [CrossRef] [PubMed]

37. De Cremoux, P.; Dalvai, M.; N’Doye, O.; Moutahir, F.; Rolland, G.; Chouchane-Mlik, O.; Assayag, F.; Lehmann-Che, J.; Kraus-Berthie, L.; Nicolas, A.; et al. HDAC inhibition does not induce estrogen receptor in human triple-negative breast cancer cell lines and patient-derived xenografts. Breast Cancer Res. Treat. 2014, 149, 81-89. [CrossRef]

38. Garmpis, N.; Christos, D.; Garmpi, A.; Kalampokas, E.; Kalampokas, T.; Spartalis, E.; Daskalopoulou, A.; Valsami, S.; Kontos, M.; Nonni, A.; et al. Histone Deacetylases as New Therapeutic Targets in Triple-negative Breast Cancer: Progress and Promises. Cancer Genom. Proteom. 2017, 14, 299-313. [CrossRef]

39. Prossnitz, E.R.; Barton, M. The G-protein-coupled estrogen receptor GPER in health and disease. Nat. Rev. Endocrinol. 2011, 7, 715-726. [CrossRef]

40. Tan, S.; Ding, K.; Chong, Q.-Y.; Zhao, J.; Liu, Y.; Shao, Y.; Zhang, Y.; Yu, Q.; Xiong, Z.; Zhang, W.; et al. Post-transcriptional regulation of ERBB2 by miR26a/b and HuR confers resistance to tamoxifen in estrogen receptor-positive breast cancer cells. $J$. Biol. Chem. 2017, 292, 13551-13564. [CrossRef] [PubMed]

41. Choi, H.-J.; Joo, H.-S.; Won, H.-Y.; Min, K.-W.; Kim, H.-Y.; Son, T.; Oh, Y.-H.; Lee, J.-Y.; Kong, G. Role of RBP2-Induced ER and IGF1R-ErbB Signaling in Tamoxifen Resistance in Breast Cancer. J. Natl. Cancer Inst. 2017, 110, 400-410. [CrossRef]

42. Xu, S.; Ge, J.; Zhang, Z.; Zhou, W. MiR-129 inhibits cell proliferation and metastasis by targeting ETS1 via PI3K/AKT/mTOR pathway in prostate cancer. Biomed. Pharmacother. 2017, 96, 634-641. [CrossRef]

43. Augereau, P.; Patsouris, A.; Bourbouloux, E.; Gourmelon, C.; Lacourtoisie, S.A.; Rigaud, D.B.; Soulié, P.; Frenel, J.-S.; Campone, M. Hormonoresistance in advanced breast cancer: A new revolution in endocrine therapy. Ther. Adv. Med. Oncol. 2017, 9, 335-346. [CrossRef] [PubMed]

44. Lu, S.; Du, Y.; Cui, F.; Feng, X.; Ma, Y.; Liu, H. Downregulation of BAG-1 in T47D cells promotes resistance to tamoxifen via activation of the PI3K/Akt/mTOR signaling pathway. Oncol. Rep. 2019, 41, 1901-1910. [CrossRef] [PubMed]

45. Jia, Y.; Zhou, J.; Luo, X.; Chen, M.; Chen, Y.; Wang, J.; Xiong, H.; Ying, X.; Hu, W.; Zhao, W.; et al. KLF4 overcomes tamoxifen resistance by suppressing MAPK signaling pathway and predicts good prognosis in breast cancer. Cell. Signal. 2018, 42, 165-175. [CrossRef]

46. Hsu, L.-H.; Chu, N.-M.; Lin, Y.-F.; Kao, S.-H. G-Protein Coupled Estrogen Receptor in Breast Cancer. Int. J. Mol. Sci. 2019, 20, 306. [CrossRef] [PubMed]

47. The FANTOM Consortium; Carninci, P.; Kasukawa, T.; Katayama, S.; Gough, J.; Frith, M.; Maeda, N.; Oyama, R.; Ravasi, T.; Lenhard, B.; et al. The Transcriptional Landscape of the Mammalian Genome. Science 2005, 309, 1559-1563. [CrossRef]

48. Guttman, M.; Amit, I.; Garber, M.; French, C.; Lin, M.F.; Feldser, D.; Huarte, M.; Zuk, O.; Carey, B.W.; Cassady, J.P.; et al. Chromatin signature reveals over a thousand highly conserved large non-coding RNAs in mammals. Nat. Cell Biol. 2009, 458, 223-227. [CrossRef] [PubMed]

49. Djebali, S.; Davis, C.A.; Merkel, A.; Dobin, A.; Lassmann, T.; Mortazavi, A.; Tanzer, A.; Lagarde, J.; Lin, W.; Schlesinger, F.; et al. Landscape of transcription in human cells. Nat. Cell Biol. 2012, 489, 101-108. [CrossRef] [PubMed]

50. Mercer, T.; Gerhardt, D.J.; Dinger, M.; Crawford, J.; Trapnell, C.; A Jeddeloh, J.; Mattick, J.; Rinn, J.L. Targeted RNA sequencing reveals the deep complexity of the human transcriptome. Nat. Biotechnol. 2011, 30, 99-104. [CrossRef] [PubMed]

51. Hangauer, M.J.; Vaughn, I.W.; McManus, M.T. Pervasive Transcription of the Human Genome Produces Thousands of Previously Unidentified Long Intergenic Noncoding RNAs. PLoS Genet. 2013, 9, e1003569. [CrossRef] [PubMed]

52. Antonov, I.V.; Mazurov, E.; Borodovsky, M.; A Medvedeva, Y. Prediction of lncRNAs and their interactions with nucleic acids: Benchmarking bioinformatics tools. Brief. Bioinform. 2018, 20, 551-564. [CrossRef] [PubMed]

53. Kasinski, A.; Slack, F.J. MicroRNAs en route to the clinic: Progress in validating and targeting microRNAs for cancer therapy. Nat. Rev. Cancer 2011, 11, 849-864. [CrossRef] [PubMed]

54. Ma, J.; Dong, C.; Ji, C. MicroRNA and drug resistance. Cancer Gene Ther. 2010, 17, 523-531. [CrossRef]

55. Mulrane, L.; McGee, S.F.; Gallagher, W.M.; O'Connor, D.P. miRNA Dysregulation in Breast Cancer. Cancer Res. 2013, 73, 6554-6562. [CrossRef] [PubMed]

56. Ahmad, A.; Ginnebaugh, K.R.; Yin, S.; Bollig-Fischer, A.; Reddy, K.B.; Sarkar, F.H. Functional role of miR-10b in tamoxifen resistance of ER-positive breast cancer cells through down-regulation of HDAC. BMC Cancer 2015, 15, 1-10. [CrossRef] [PubMed] 
57. Cui, J.; Yang, Y.; Li, H.; Leng, Y.; Qian, K.; Huang, Q.; Zhang, C.; Lu, Z.; Chen, J.; Sun, T.; et al. MiR-873 regulates ER $\alpha$ transcriptional activity and tamoxifen resistance via targeting CDK3 in breast cancer cells. Oncogene 2014, 34, 3895-3907. [CrossRef]

58. Yu, X.; Luo, A.; Liu, Y.; Wang, S.; Li, Y.; Shi, W.; Liu, Z.; Qu, X. MiR-214 increases the sensitivity of breast cancer cells to tamoxifen and fulvestrant through inhibition of autophagy. Mol. Cancer 2015, 14, 1-16. [CrossRef]

59. Zhu, J.; Zou, Z.; Nie, P.; Kou, X.; Wu, B.; Wang, S.; Song, Z.; He, J. Downregulation of microRNA-27b-3p enhances tamoxifen resistance in breast cancer by increasing NR5A2 and CREB1 expression. Cell Death Dis. 2016, 7, e2454. [CrossRef] [PubMed]

60. Chen, M.-J.; Cheng, Y.-M.; Chen, C.-C.; Chen, Y.-C.; Shen, C.-J. MiR-148a and miR-152 reduce tamoxifen resistance in ER+ breast cancer via downregulating ALCAM. Biochem. Biophys. Res. Commun. 2017, 483, 840-846. [CrossRef]

61. Guttman, M.; Russell, P.; Ingolia, N.T.; Weissman, J.S.; Lander, E.S. Ribosome Profiling Provides Evidence that Large Noncoding RNAs Do Not Encode Proteins. Cell 2013, 154, 240-251. [CrossRef]

62. Gil, N.; Ulitsky, I. Regulation of gene expression by cis-acting long non-coding RNAs. Nat. Rev. Genet. 2019, 21, 102-117. [CrossRef]

63. Derrien, T.; Johnson, R.; Bussotti, G.; Tanzer, A.; Djebali, S.; Tilgner, H.; Guernec, G.; Martin, D.; Merkel, A.; Knowles, D.G.; et al. The GENCODE v7 catalog of human long noncoding RNAs: Analysis of their gene structure, evolution, and expression. Genome Res. 2012, 22, 1775-1789. [CrossRef]

64. Wu, P.; Mo, Y.; Peng, M.; Tang, T.; Zhong, Y.; Deng, X.; Xiong, F.; Guo, C.; Wu, X.; Li, Y.; et al. Emerging role of tumor-related functional peptides encoded by lncRNA and circRNA. Mol. Cancer 2020, 19, 1-14. [CrossRef]

65. Lyle, R.; Watanabe, D.; Vruchte, D.T.; Lerchner, W.; Smrzka, O.W.; Wutz, A.; Schageman, J.; Hahner, L.; Davies, C.; Barlow, D.P. The imprinted antisense RNA at the Igf2r locus overlaps but does not imprint Mas. Nat. Genet. 2000, 25, 19-21. [CrossRef] [PubMed]

66. Rinn, J.; Kertesz, M.; Wang, J.; Squazzo, S.L.; Xu, X.; Brugmann, S.A.; Goodnough, L.H.; Helms, J.A.; Farnham, P.; Segal, E.; et al. Functional Demarcation of Active and Silent Chromatin Domains in Human HOX Loci by Noncoding RNAs. Cell 2007, 129, 1311-1323. [CrossRef] [PubMed]

67. Mercer, T.; Dinger, M.; Sunkin, S.M.; Mehler, M.F.; Mattick, J. Specific expression of long noncoding RNAs in the mouse brain. Proc. Natl. Acad. Sci. USA 2008, 105, 716-721. [CrossRef] [PubMed]

68. Hung, T.; Wang, Y.; Lin, M.F.; Koegel, A.K.; Kotake, Y.; Grant, G.; Horlings, H.M.; Shah, N.; Umbricht, C.; Wang, P.; et al. Extensive and coordinated transcription of noncoding RNAs within cell-cycle promoters. Nat. Genet. 2011, 43, 621-629. [CrossRef]

69. Li, J.; Tian, H.; Yang, J.; Gong, Z. Long Noncoding RNAs Regulate Cell Growth, Proliferation, and Apoptosis. DNA Cell Biol. 2016, 35, 459-470. [CrossRef] [PubMed]

70. Huarte, M.; Guttman, M.; Feldser, D.; Garber, M.; Koziol, M.; Kenzelmann-Broz, D.; Khalil, A.M.; Zuk, O.; Amit, I.; Rabani, M.; et al. A Large Intergenic Noncoding RNA Induced by p53 Mediates Global Gene Repression in the p53 Response. Cell 2010, 142, 409-419. [CrossRef]

71. Latos, P.A.; Pauler, F.M.; Koerner, M.V.; Şenergin, H.B.; Hudson, Q.; Stocsits, R.R.; Allhoff, W.; Stricker, S.; Klement, R.M.; Warczok, K.E.; et al. Airn Transcriptional Overlap, But Not Its lncRNA Products, Induces Imprinted Igf2r Silencing. Science 2012, 338, 1469-1472. [CrossRef]

72. Santoro, F.; Mayer, D.; Klement, R.M.; Warczok, K.E.; Stukalov, A.; Barlow, D.P.; Pauler, F.M. Imprinted Igf2r silencing depends on continuous Airn lncRNA expression and is not restricted to a developmental window. Development 2013, 140, 1184-1195. [CrossRef] [PubMed]

73. Guttman, M.; Donaghey, J.; Carey, B.W.; Garber, M.; Grenier, J.K.; Munson, G.; Young, G.; Lucas, A.B.; Ach, R.; Bruhn, L.; et al. lincRNAs act in the circuitry controlling pluripotency and differentiation. Nat. Cell Biol. 2011, 477, 295-300. [CrossRef]

74. Ng, S.-Y.; Johnson, R.; Stanton, L.W. Human long non-coding RNAs promote pluripotency and neuronal differentiation by association with chromatin modifiers and transcription factors. EMBO J. 2011, 31, 522-533. [CrossRef]

75. Lin, N.; Chang, K.-Y.; Li, Z.; Gates, K.; Rana, Z.A.; Dang, J.; Zhang, D.; Han, T.; Yang, C.-S.; Cunningham, T.; et al. An Evolutionarily Conserved Long Noncoding RNA TUNA Controls Pluripotency and Neural Lineage Commitment. Mol. Cell 2014, 53, 1005-1019. [CrossRef] [PubMed]

76. Yu, C.-Y.; Kuo, H.-C. The Trans-Spliced Long Noncoding RNA tsRMSTImpedes Human Embryonic Stem Cell Differentiation Through WNT5A-Mediated Inhibition of the Epithelial-to-Mesenchymal Transition. Stem Cells 2016, 34, $2052-2062$. [CrossRef] [PubMed]

77. Obaid, M.; Udden, S.M.N.; Deb, P.; Shihabeddin, N.; Zaki, H.; Mandal, S.S. LncRNA HOTAIR regulates lipopolysaccharideinduced cytokine expression and inflammatory response in macrophages. Sci. Rep. 2018, 8, 1-18. [CrossRef] [PubMed]

78. Gupta, R.A.; Shah, N.; Wang, K.C.; Kim, J.; Horlings, H.M.; Wong, D.J.; Tsai, M.-C.; Hung, T.; Argani, P.; Rinn, J.; et al. Long noncoding RNA HOTAIR reprograms chromatin state to promote cancer metastasis. Nat. Cell Biol. 2010, 464, 1071-1076. [CrossRef]

79. Huang, R.; Wang, X.; Zhang, W.; Zhangyuan, G.; Jin, K.; Yu, W.; Xie, Y.; Xu, X.; Wang, H.; Sun, B. Down-Regulation of LncRNA DGCR5 Correlates with Poor Prognosis in Hepatocellular Carcinoma. Cell. Physiol. Biochem. 2016, 40, 707-715. [CrossRef] [PubMed]

80. Schmidt, K.; Joyce, C.E.; Buquicchio, F.; Brown, A.; Ritz, J.; Distel, R.J.; Yoon, C.H.; Novina, C.D. The lncRNA SLNCR1 Mediates Melanoma Invasion through a Conserved SRA1-like Region. Cell Rep. 2016, 15, 2025-2037. [CrossRef]

81. de Oliveira, J.C.; Oliveira, L.C.; Mathias, C.; Pedroso, G.A.; Lemos, D.S.; Salviano-Silva, A.; Jucoski, T.S.; Lobo-Alves, S.C.; Zambalde, E.P.; Cipolla, G.A.; et al. Long non-coding RNAs in cancer: Another layer of complexity. J. Gene Med. 2019, 21, e3065. [PubMed] 
82. Huang, L.; Liang, G.; Zhang, Q.; Zhao, W. The Role of Long Noncoding RNAs in Antiestrogen Resistance in Breast Cancer: An Overview and Update. J. Breast Cancer 2020, 23, 129-140. [CrossRef] [PubMed]

83. Manavalan, T.T.; Teng, Y.; Appana, S.N.; Datta, S.; Kalbfleisch, T.S.; Li, Y.; Klinge, C.M. Differential expression of microRNA expression in tamoxifen-sensitive MCF-7 versus tamoxifen-resistant LY2 human breast cancer cells. Cancer Lett. 2011, 313, 26-43. [CrossRef]

84. Han, X.; Li, Q.; Liu, C.; Wang, C.; Li, Y. Overexpression miR-24-3p repressed Bim expression to confer tamoxifen resistance in breast cancer. J. Cell. Biochem. 2019, 120, 12966-12976. [CrossRef]

85. Wang, J.; Xie, S.; Yang, J.; Xiong, H.; Jia, Y.; Zhou, Y.; Chen, Y.; Ying, X.; Chen, C.; Ye, C.; et al. The long noncoding RNA H19 promotes tamoxifen resistance in breast cancer via autophagy. J. Hematol. Oncol. 2019, 12, 1-14. [CrossRef] [PubMed]

86. E Miller, T.; Ghoshal, K.; Ramaswamy, B.; Roy, S.; Datta, J.; Shapiro, C.L.; Jacob, S.; Majumder, S. MicroRNA-221/222 Confers Tamoxifen Resistance in Breast Cancer by Targeting p27Kip. J. Biol. Chem. 2008, 283, 29897-29903. [CrossRef]

87. Zhao, J.-J.; Lin, J.; Yang, H.; Kong, W.; He, L.; Ma, X.; Coppola, D.; Cheng, J.Q. MicroRNA-221/222 Negatively Regulates Estrogen Receptor $\alpha$ and Is Associated with Tamoxifen Resistance in Breast Cancer. J. Biol. Chem. 2008, 283, 31079-31087. [CrossRef]

88. Han, S.-H.; Kim, H.J.; Gwak, J.M.; Kim, M.; Chung, Y.R.; Park, S.Y. MicroRNA-222 Expression as a Predictive Marker for Tumor Progression in Hormone Receptor-Positive Breast Cancer. J. Breast Cancer 2017, 20, 35-44. [CrossRef] [PubMed]

89. Kim, Y.S.; Park, S.J.; Lee, Y.S.; Kong, H.K.; Park, J.H. miRNAs involved in LY6K and estrogen receptor $\alpha$ contribute to tamoxifensusceptibility in breast cancer. Oncotarget 2016, 7, 42261-42273. [CrossRef]

90. Martin, E.C.; Conger, A.K.; Yan, T.J.; Hoang, V.T.; Miller, D.F.B.; Buechlein, A.; Rusch, D.B.; Nephew, K.P.; Collins-Burow, B.M.; Burow, M.E. MicroRNA-335-5p and -3p synergize to inhibit estrogen receptor alpha expression and promote tamoxifen resistance. FEBS Lett. 2016, 591, 382-392. [CrossRef] [PubMed]

91. Cochrane, D.R.; Cittelly, D.; Howe, E.; Spoelstra, N.S.; McKinsey, E.L.; LaPara, K.; Elias, A.; Yee, D.; Richer, J.K. MicroRNAs Link Estrogen Receptor Alpha Status and Dicer Levels in Breast Cancer. Horm. Cancer 2010, 1, 306-319. [CrossRef]

92. Di Leva, G.; Gasparini, P.; Piovan, C.; Ngankeu, A.; Garofalo, M.; Taccioli, C.; Iorio, M.; Li, M.; Volinia, S.; Alder, H.; et al. MicroRNA Cluster 221-222 and Estrogen Receptor $\alpha$ Interactions in Breast Cancer. J. Natl. Cancer Inst. 2010, 102, 706-721. [CrossRef] [PubMed]

93. Wei, Y.; Lai, X.; Yu, S.; Chen, S.; Ma, Y.; Zhang, Y.; Li, H.; Zhu, X.; Yao, L.; Zhang, J. Exosomal miR-221/222 enhances tamoxifen resistance in recipient ER-positive breast cancer cells. Breast Cancer Res. Treat. 2014, 147, 423-431. [CrossRef] [PubMed]

94. Zhang, W.; Wu, M.; Chong, Q.-Y.; Zhang, M.; Zhang, X.; Hu, L.; Zhong, Y.; Qian, P.; Kong, X.J.; Tan, S.; et al. Loss of EstrogenRegulated MIR135A1 at 3p21.1 Promotes Tamoxifen Resistance in Breast Cancer. Cancer Res. 2018, 78, 4915-4928. [CrossRef]

95. Pagano, M.T.; Ortona, E.; Dupuis, M.L. A Role for Estrogen Receptor alpha36 in Cancer Progression. Front. Endocrinol. 2020, 11, 506. [CrossRef]

96. Wang, Y.; Pan, X.; Li, Y.; Wang, R.; Yang, Y.; Jiang, B.; Sun, G.; Shao, C.; Wang, M.; Gong, Y. CUL4B renders breast cancer cells tamoxifen-resistant via miR -32-5p/ ER - $\alpha 36$ axis. J. Pathol. 2021, 254, 185-198. [CrossRef]

97. Shou, J.; Massarweh, S.; Osborne, C.K.; Wakeling, A.E.; Ali, S.; Weiss, H.; Schiff, R. Mechanisms of Tamoxifen Resistance: Increased Estrogen Receptor-HER2/neu Cross-Talk in ER/HER2-Positive Breast Cancer. J. Natl. Cancer Inst. 2004, 96, 926-935. [CrossRef]

98. Musgrove, E.A.; Sutherland, R.L. Biological determinants of endocrine resistance in breast cancer. Nat. Rev. Cancer 2009, 9, 631-643. [CrossRef] [PubMed]

99. Osborne, C.K.; Schiff, R. Mechanisms of Endocrine Resistance in Breast Cancer. Annu. Rev. Med. 2011, 62, 233-247. [CrossRef]

100. Milella, M.; Falcone, I.; Conciatori, F.; Incani, U.C.; Del Curatolo, A.; Inzerilli, N.; Nuzzo, C.M.A.; Vaccaro, V.; Vari, S.; Cognetti, F.; et al. PTEN: Multiple functions in human malignant tumors. Front. Oncol. 2015, 5, 24. [CrossRef]

101. Shi, W.; Gerster, K.; Alajez, N.M.; Tsang, J.; Waldron, L.; Pintilie, M.; Hui, A.B.; Sykes, J.; P’Ng, C.; Miller, N.; et al. MicroRNA-301 Mediates Proliferation and Invasion in Human Breast Cancer. Cancer Res. 2011, 71, 2926-2937. [CrossRef]

102. Ward, A.; Shukla, K.; Balwierz, A.; Soons, Z.; König, R.; Şahin, Z.; Wiemann, S. MicroRNA -519a is a novel oncomir conferring tamoxifen resistance by targeting a network of tumour-suppressor genes in ER + breast cancer. J. Pathol. 2014, 233, 368-379. [CrossRef] [PubMed]

103. Phuong, N.T.T.; Kim, S.K.; Im, J.H.; Yang, J.W.; Choi, M.C.; Lim, S.C.; Lee, K.Y.; Kim, Y.-M.; Yoon, J.H.; Kang, K.W. Induction of methionine adenosyltransferase 2A in tamoxifen-resistant breast cancer cells. Oncotarget 2015, 7, 13902-13916. [CrossRef]

104. Muluhngwi, P.; Krishna, A.; Vittitow, S.L.; Napier, J.T.; Richardson, K.M.; Ellis, M.; Mott, J.L.; Klinge, C.M. Tamoxifen differentially regulates miR-29b-1 and miR-29a expression depending on endocrine-sensitivity in breast cancer cells. Cancer Lett. 2017, 388, 230-238. [CrossRef] [PubMed]

105. Huang, W.-T.; Tsai, Y.-H.; Chen, S.-H.; Kuo, C.-W.; Kuo, Y.-L.; Lee, K.-T.; Chen, W.-C.; Wu, P.C.; Chuang, C.-Y.; Cheng, S.M.; et al. HDAC2 and HDAC5 Up-Regulations Modulate Survivin and miR-125a-5p Expressions and Promote Hormone Therapy Resistance in Estrogen Receptor Positive Breast Cancer Cells. Front. Pharmacol. 2017, 8. [CrossRef] [PubMed]

106. Lü, M.; Ding, K.; Zhang, G.; Yin, M.; Yao, G.; Tian, H.; Lian, J.; Liu, L.; Liang, M.; Zhu, T.; et al. MicroRNA-320a sensitizes tamoxifen-resistant breast cancer cells to tamoxifen by targeting ARPP-19 and ERR $\gamma^{*}$. Sci. Rep. 2015, 5, srep08735. [CrossRef] [PubMed]

107. Li, X.; Wu, Y.; Liu, A.; Tang, X. MiR-27b is epigenetically downregulated in tamoxifen resistant breast cancer cells due to promoter methylation and regulates tamoxifen sensitivity by targeting HMGB. Biochem. Biophys. Res. Commun. 2016, 477, 768-773. [CrossRef] 
108. Zhong, X.; Xie, G.; Zhang, Z.; Wang, Z.; Wang, Y.; Wang, Y.; Qiu, Y.; Li, L.; Bu, H.; Li, J.; et al. MiR-4653-3p and its target gene FRS2 are prognostic biomarkers for hormone receptor positive breast cancer patients receiving tamoxifen as adjuvant endocrine therapy. Oncotarget 2016, 7, 61166-61182. [CrossRef]

109. Zheng, L.; Meng, X.; Li, X.; Zhang, Y.; Li, C.; Xiang, C.; Xing, Y.; Xia, Y.; Xi, T. miR-125a-3p inhibits ER $\alpha$ transactivation and overrides tamoxifen resistance by targeting CDK3 in estrogen receptor-positive breast cancer. FASEB J. 2018, 32, 588-600. [CrossRef]

110. He, M.; Jin, Q.; Chen, C.; Liu, Y.; Ye, X.; Jiang, Y.; Ji, F.; Qian, H.; Gan, D.; Yue, S.; et al. The miR-186-3p/EREG axis orchestrates tamoxifen resistance and aerobic glycolysis in breast cancer cells. Oncogene 2019, 38, 5551-5565. [CrossRef]

111. Liu, J.; Zhu, S.; Tang, W.; Huang, Q.; Mei, Y.; Yang, H. Exosomes from tamoxifen-resistant breast cancer cells transmit drug resistance partly by delivering miR-9-5p. Cancer Cell Int. 2021, 21, 1-15. [CrossRef]

112. Pillai, M.M.; Gillen, A.; Yamamoto, T.M.; Kline, E.; Brown, J.; Flory, K.; Hesselberth, J.; Kabos, P. HITS-CLIP reveals key regulators of nuclear receptor signaling in breast cancer. Breast Cancer Res. Treat. 2014, 146, 85-97. [CrossRef]

113. Wang, Y.; Wang, Q.; Li, X.; Luo, G.; Shen, M.; Shi, J.; Wang, X.; Tang, L. Paeoniflorin Sensitizes Breast Cancer Cells to Tamoxifen by Downregulating microRNA-15b via the FOXO1/CCND1/ $\beta$-Catenin Axis. Drug Des. Dev. Ther. 2021, 15, 245-257. [CrossRef]

114. Luengo-Gil, G.; García-Martínez, E.; Chaves-Benito, A.; Conesa-Zamora, P.; Manzano, E.N.; González-Billalabeitia, E.; García-Garre, E.; Martínez-Carrasco, A.; Vicente, V.; De La Peña, F.A. Clinical and biological impact of miR-18a expression in breast cancer after neoadjuvant chemotherapy. Cell. Oncol. 2019, 42, 627-644. [CrossRef]

115. Chen, C.; Liang, Z.; Huang, W.; Li, X.; Zhou, F.; Hu, X.; Han, M.; Ding, X.; Xiang, S. Eps8 regulates cellular proliferation and migration of breast cancer. Int. J. Oncol. 2014, 46, 205-214. [CrossRef] [PubMed]

116. Yu, X.; Li, R.; Shi, W.; Jiang, T.; Wang, Y.; Li, C.; Qu, X. Silencing of MicroRNA-21 confers the sensitivity to tamoxifen and fulvestrant by enhancing autophagic cell death through inhibition of the PI3K-AKT-mTOR pathway in breast cancer cells. Biomed. Pharmacother. 2016, 77, 37-44. [CrossRef] [PubMed]

117. Ye, P.; Fang, C.; Zeng, H.; Shi, Y.; Pan, Z.; An, N.; He, K.; Zhang, L.; Long, X. Differential microRNA expression profiles in tamoxifen-resistant human breast cancer cell lines induced by two methods. Oncol. Lett. 2018, 15, 3532-3539. [CrossRef]

118. Yang, C.; Zhang, X.; Han, B.; Tian, X. Sensitization to tamoxifen by tanshinone IIA in tamoxifen-resistant breast cancer cells in vitro. Inter. J. Clin. Exper. Med. 2017, 10, 2660-2671.

119. Bacci, M.; Lorito, N.; Ippolito, L.; Ramazzotti, M.; Luti, S.; Romagnoli, S.; Parri, M.; Bianchini, F.; Cappellesso, F.; Virga, F.; et al. Reprogramming of Amino Acid Transporters to Support Aspartate and Glutamate Dependency Sustains Endocrine Resistance in Breast Cancer. Cell Rep. 2019, 28, 104-118.e8. [CrossRef] [PubMed]

120. Zhang, Y.; Chen, D.; Zhang, G.; Wu, X.; Zhou, L.; Lin, Y.; Ding, J.; An, F.; Zhan, Q. MicroRNA-23b-3p promotes pancreatic cancer cell tumorigenesis and metastasis via the JAK/PI3K and Akt/NF-kB signaling pathways. Oncol. Lett. 2020, 20, 1. [CrossRef]

121. Cun, J.; Yang, Q. Bioinformatics-based interaction analysis of miR-92a-3p and key genes in tamoxifen-resistant breast cancer cells. Biomed. Pharmacother. 2018, 107, 117-128. [CrossRef] [PubMed]

122. Sachdeva, M.; Wu, H.; Ru, P.; Hwang, L.; Trieu, V.; Mo, Y.-Y. MicroRNA-101-mediated Akt activation and estrogen-independent growth. Oncogene 2010, 30, 822-831. [CrossRef]

123. Shen, R.; Wang, Y.; Wang, C.-X.; Yin, M.; Liu, H.-L.; Chen, J.-P.; Han, J.-Q.; Wang, W.-B. MiRNA-155 mediates TAM resistance by modulating SOCS6-STAT3 signalling pathway in breast cancer. Am. J. Transl. Res. 2015, 7, 2115-2126.

124. Cittelly, D.M.; Das, P.M.; Spoelstra, N.S.; Edgerton, S.M.; Richer, J.K.; Thor, A.D.; E Jones, F. Downregulation of miR-342 is associated with tamoxifen resistant breast tumors. Mol. Cancer 2010, 9, 317. [CrossRef] [PubMed]

125. Eskiler, G.G.; Cecener, G.; Dikmen, G.; Egeli, U.; Tunca, B. Solid lipid nanoparticles: Reversal of tamoxifen resistance in breast cancer. Eur. J. Pharm. Sci. 2018, 120, 73-88. [CrossRef]

126. Zhu, Z.-M.; Liu, F.-T.; Chen, X. Low Expression of LncRNA Cancer Susceptibility Candidate 2 and its Clinical Significance in Cancer Tissues. Cell. Physiol. Biochem. 2018, 46, 1643-1649. [CrossRef] [PubMed]

127. Liu, Y.; Li, M.; Yu, H.; Piao, H. lncRNA CYTOR promotes tamoxifen resistance in breast cancer cells via sponging miR-125a-5p. Int. J. Mol. Med. 2019, 45, 497-509. [CrossRef]

128. Jiang, H.; Cheng, L.; Hu, P.; Liu, R. MicroRNA-663b mediates TAM resistance in breast cancer by modulating TP73 expression. Mol. Med. Rep. 2018, 18, 1120-1126. [CrossRef] [PubMed]

129. Klinge, C.M.; Piell, K.M.; Tooley, C.S.; Rouchka, E.C. HNRNPA2/B1 is upregulated in endocrine-resistant LCC9 breast cancer cells and alters the miRNA transcriptome when overexpressed in MCF-7 cells. Sci. Rep. 2019, 9, 1-22. [CrossRef]

130. Zhao, Y.; Deng, C.; Lu, W.; Xiao, J.; Ma, D.; Guo, M.; Recker, R.R.; Gatalica, Z.; Wang, Z.; Xiao, G.G. let-7 MicroRNAs Induce Tamoxifen Sensitivity by Downregulation of Estrogen Receptor $\alpha$ Signaling in Breast Cancer. Mol. Med. 2011, 17, 1233-1241. [CrossRef]

131. Chu, J.; Zhu, Y.; Liu, Y.; Sun, L.; Lv, X.; Wu, Y.; Hu, P.; Su, F.; Gong, C.; Song, E.; et al. E2F7 overexpression leads to tamoxifen resistance in breast cancer cells by competing with E2F1 at miR-15a/16 promoter. Oncotarget 2015, 6, 31944-31957. [CrossRef]

132. Klinge, C.M.; Riggs, K.A.; Wickramasinghe, N.S.; Emberts, C.G.; McConda, D.B.; Barry, P.N.; Magnusen, J.E. Estrogen receptor alpha 46 is reduced in tamoxifen resistant breast cancer cells and re-expression inhibits cell proliferation and estrogen receptor alpha 66-regulated target gene transcription. Mol. Cell. Endocrinol. 2010, 323, 268-276. [CrossRef]

133. Ljepoja, B.; García-Roman, J.; Sommer, A.-K.; Wagner, E.; Roidl, A. MiRNA-27a sensitizes breast cancer cells to treatment with Selective Estrogen Receptor Modulators. Breast 2019, 43, 31-38. [CrossRef] [PubMed] 
134. Ujihira, T.; Ikeda, K.; Suzuki, T.; Yamaga, R.; Sato, W.; Horieinoue, K.; Shigekawa, T.; Osaki, A.; Saeki, T.; Okamoto, K.; et al. MicroRNA-574-3p, identified by microRNA library-based functional screening, modulates tamoxifen response in breast cancer. Sci. Rep. 2015, 5, 7641. [CrossRef]

135. Li, F.; Miao, L.; Xue, T.; Qin, H.; Mondal, S.; Thompson, P.R.; Coonrod, S.A.; Liu, X.; Zhang, X. Inhibiting PAD2 enhances the antitumor effect of docetaxel in tamoxifen-resistant breast cancer cells. J. Exp. Clin. Cancer Res. 2019, 38, 1-15. [CrossRef] [PubMed]

136. Jin, K.; Park, S.; Teo, W.W.; Korangath, P.; Cho, S.; Yoshida, T.; Gyorffy, B.; Goswami, C.P.; Nakshatri, H.; Cruz, L.-A.; et al. HOXB7 Is an ER $\alpha$ Cofactor in the Activation of HER2 and Multiple ER Target Genes Leading to Endocrine Resistance. Cancer Discov. 2015, 5, 944-959. [CrossRef]

137. Manavalan, T.T.; Teng, Y.; Litchfield, L.M.; Muluhngwi, P.; Al-Rayyan, N.; Klinge, C.M. Reduced Expression of miR-200 Family Members Contributes to Antiestrogen Resistance in LY2 Human Breast Cancer Cells. PLoS ONE 2013, 8, e62334. [CrossRef]

138. Young, J.; Kawaguchi, T.; Yan, L.; Qi, Q.; Liu, S.; Takabe, K. Tamoxifen sensitivity-related microRNA-342 is a useful biomarker for breast cancer survival. Oncotarget 2017, 8, 99978-99989. [CrossRef]

139. Li, Y.; Liu, L.; Lv, Y.; Zhang, Y.; Zhang, L.; Yu, H.; Tian, W.; Zhang, Z.; Cui, S. Silencing long non-coding RNA HNF1A-AS1 inhibits growth and resistance to TAM of breast cancer cells via the microRNA-363/SERTAD3 axis. J. Drug Target. 2021, 1-31. [CrossRef]

140. Lin, Y.; Fu, F.; Chen, Y.; Qiu, W.; Lin, S.; Yang, P.; Huang, M.; Wang, C. Genetic variants in long noncoding RNA H19 contribute to the risk of breast cancer in a southeast China Han population. OncoTargets Ther. 2017, 10, 4369-4378. [CrossRef]

141. Ikeda, K.; Horie-Inoue, K.; Ueno, T.; Suzuki, T.; Sato, W.; Shigekawa, T.; Osaki, A.; Saeki, T.; Berezikov, E.; Mano, H.; et al. miR-378a-3p modulates tamoxifen sensitivity in breast cancer MCF-7 cells through targeting GOLT1A. Sci. Rep. 2015, 5, 13170. [CrossRef]

142. Li, J.; Lu, M.; Jin, J.; Lu, X.; Xu, T.; Jin, S. miR-449a Suppresses Tamoxifen Resistance in Human Breast Cancer Cells by Targeting ADAM. Cell. Physiol. Biochem. 2018, 50, 136-149. [CrossRef]

143. Bergamaschi, A.; Katzenellenbogen, B.S. Tamoxifen downregulation of miR-451 increases 14-3-3 $\zeta$ and promotes breast cancer cell survival and endocrine resistance. Oncogene 2011, 31, 39-47. [CrossRef]

144. Liu, Z.-R.; Song, Y.; Wan, L.-H.; Zhang, Y.-Y.; Zhou, L.-M. Over-expression of miR-451a can enhance the sensitivity of breast cancer cells to tamoxifen by regulating 14-3-3द, estrogen receptor $\alpha$, and autophagy. Life Sci. 2016, 149, 104-113. [CrossRef]

145. Wei, Y.; Li, H.; Qu, Q. miR-484 suppresses endocrine therapy-resistant cells by inhibiting KLF4-induced cancer stem cells in estrogen receptor-positive cancers. Breast Cancer 2020, 28, 175-186. [CrossRef]

146. Zhang, X.; Zhang, B.; Zhang, P.; Lian, L.; Li, L.; Qiu, Z.; Qian, K.; Chen, A.; Liu, Q.; Jiang, Y.; et al. Norcantharidin regulates ER $\alpha$ signaling and tamoxifen resistance via targeting miR-873/CDK3 in breast cancer cells. PLoS ONE 2019, 14, e0217181. [CrossRef]

147. Peng, W.-X.; Huang, J.; Yang, L.; Gong, A.-H.; Mo, Y.-Y. Linc-RoR promotes MAPK/ERK signaling and confers estrogenindependent growth of breast cancer. Mol. Cancer 2017, 16, 1-11. [CrossRef]

148. Li, Y.; Jiang, B.; Zhu, H.; Qu, X.; Zhao, L.; Tan, Y.; Jiang, Y.; Liao, M.; Wu, X. Inhibition of long non-coding RNA ROR reverses resistance to Tamoxifen by inducing autophagy in breast cancer. Tumor Biol. 2017, 39. [CrossRef]

149. Basak, P.; Chatterjee, S.; Bhat, V.; Su, A.; Jin, H.; Lee-Wing, V.; Liu, Q.; Hu, P.; Murphy, L.C.; Raouf, A. Long Non-Coding RNA H19 Acts as an Estrogen Receptor Modulator that is Required for Endocrine Therapy Resistance in ER+ Breast Cancer Cells. Cell. Physiol. Biochem. 2018, 51, 1518-1532. [CrossRef] [PubMed]

150. Gao, H.; Hao, G.; Sun, Y.; Li, L.; Wang, Y. Long noncoding RNA H19 mediated the chemosensitivity of breast cancer cells via Wnt pathway and EMT process. OncoTargets Ther. 2018, 11, 8001-8012. [CrossRef] [PubMed]

151. Glick, D.; Barth, S.; MacLeod, K.F. Autophagy: Cellular and molecular mechanisms. J. Pathol. 2010, 221, 3-12. [CrossRef] [PubMed]

152. Li, Y.-J.; Lei, Y.-H.; Yao, N.; Wang, C.-R.; Hu, N.; Ye, W.-C.; Zhang, D.-M.; Chen, Z.-S. Autophagy and multidrug resistance in cancer. Chin. J. Cancer 2017, 36, 1-10. [CrossRef]

153. Wilde, L.; Tanson, K.; Curry, J.; Martinez-Outschoorn, U. Autophagy in cancer: A complex relationship. Biochem. J. 2018, 475, 1939-1954. [CrossRef]

154. Li, X.; Wu, Y.; Liu, A.; Tang, X. Long non-coding RNA UCA1 enhances tamoxifen resistance in breast cancer cells through a miR-18a-HIF1 $\alpha$ feedback regulatory loop. Tumor Biol. 2016, 37, 14733-14743. [CrossRef] [PubMed]

155. Liu, H.; Wang, G.; Yang, L.; Qu, J.; Yang, Z.; Zhou, X. Knockdown of Long Non-Coding RNA UCA1 Increases the Tamoxifen Sensitivity of Breast Cancer Cells through Inhibition of Wnt/ $\beta$-Catenin Pathway. PLoS ONE 2016, 11, e0168406. [CrossRef]

156. Wu, C.; Luo, J. Long Non-Coding RNA (lncRNA) Urothelial Carcinoma-Associated 1 (UCA1) Enhances Tamoxifen Resistance in Breast Cancer Cells via Inhibiting mTOR Signaling Pathway. Med. Sci. Monit. 2016, 22, 3860-3867. [CrossRef] [PubMed]

157. Xu, C.G.; Yang, M.F.; Ren, Y.Q.; Wu, C.H.; Wang, L.Q. Exosomes mediated transfer of lncRNA UCA1 results in increased tamoxifen resistance in breast cancer cells. Eur. Rev. Med. Pharmacol. Sci. 2016, 20, 4362-4368. [PubMed]

158. Zhang, Y.; Xu, L.; Li, A.; Han, X. The roles of ZEB1 in tumorigenic progression and epigenetic modifications. Biomed. Pharmacother. 2019, 110, 400-408. [CrossRef] [PubMed]

159. Li, Z.; Yu, D.; Li, H.; Lv, Y.; Li, S. Long non-coding RNA UCA1 confers tamoxifen resistance in breast cancer endocrinotherapy through regulation of the EZH2/p21 axis and the PI3K/AKT signaling pathway. Int. J. Oncol. 2019, 54, $1033-1042$. [CrossRef] [PubMed]

160. Zhang, D.; Cai, Y.; He, J. Long noncoding RNA CCAT2 promotes breast tumor growth by regulating the Wnt signaling pathway. OncoTargets Ther. 2015, 8, 2657-2664. [CrossRef] 
161. Wu, Z.; Li, Y.; Wu, Y.; Wang, Y.; Nian, W. Long non-coding RNA CCAT2 promotes the breast cancer growth and metastasis by regulating TGF- $\beta$ signaling pathway. Eur. Rev. Med. Pharmacol. Sci. 2017, 21, 706-714.

162. Cai, Y.; He, J.; Zhang, D. Супрессия экспрессии длинной некодирующей РНКССАТ2 повышаетответ на тамоксифен клеток рака молочной железы, резистентных к тамоксифену. Молекулярная биология 2016, 50, 821-827. [CrossRef]

163. Sun, W.; Li, A.-Q.; Zhou, P.; Jiang, Y.-Z.; Jin, X.; Liu, Y.-R.; Guo, Y.-J.; Yang, W.-T.; Shao, Z.-M.; Xu, X.-E. DSCAM-AS1 regulates the G1 / $\mathrm{S}$ cell cycle transition and is an independent prognostic factor of poor survival in luminal breast cancer patients treated with endocrine therapy. Cancer Med. 2018, 7, 6137-6146. [CrossRef]

164. Niknafs, Y.S.; Han, S.; Ma, T.; Speers, C.; Zhang, C.; Wilder-Romans, K.; Iyer, M.K.; Pitchiaya, S.; Malik, R.; Hosono, Y.; et al. The lncRNA landscape of breast cancer reveals a role for DSCAM-AS1 in breast cancer progression. Nat. Commun. 2016, 7, 12791. [CrossRef]

165. Ma, Y.; Bu, D.; Long, J.; Chai, W.; Dong, J. LncRNA DSCAM-AS1 acts as a sponge of miR-137 to enhance Tamoxifen resistance in breast cancer. J. Cell. Physiol. 2018, 234, 2880-2894. [CrossRef] [PubMed]

166. Xue, X.; Yang, Y.A.; Zhang, A.; Fong, K.-W.; Kim, J.; Song, B.; Li, S.; Zhao, J.C.; Yu, J. LncRNA HOTAIR enhances ER signaling and confers tamoxifen resistance in breast cancer. Oncogene 2015, 35, 2746-2755. [CrossRef] [PubMed]

167. Bhan, A.; Hussain, I.; Ansari, K.I.; Kasiri, S.; Bashyal, A.; Mandal, S.S. Antisense Transcript Long Noncoding RNA (lncRNA) HOTAIR is Transcriptionally Induced by Estradiol. J. Mol. Biol. 2013, 425, 3707-3722. [CrossRef]

168. Tsai, M.-C.; Manor, O.; Wan, Y.; Mosammaparast, N.; Wang, J.; Lan, F.; Shi, Y.; Segal, E.; Chang, H.Y. Long Noncoding RNA as Modular Scaffold of Histone Modification Complexes. Science 2010, 329, 689-693. [CrossRef]

169. Chu, C.; Qu, K.; Zhong, F.; Artandi, S.E.; Chang, H.Y. Genomic Maps of Long Noncoding RNA Occupancy Reveal Principles of RNA-Chromatin Interactions. Mol. Cell 2011, 44, 667-678. [CrossRef] [PubMed]

170. Han, L.; Zhang, H.-C.; Li, L.; Li, C.-X.; Di, X.; Qu, X. Downregulation of Long Noncoding RNA HOTAIR and EZH2 Induces Apoptosis and Inhibits Proliferation, Invasion, and Migration of Human Breast Cancer Cells. Cancer Biother. Radiopharm. 2018, 33, 241-251. [CrossRef]

171. Ma, T.; Liang, Y.; Li, Y.; Song, X.; Zhang, N.; Li, X.; Chen, B.; Zhao, W.; Wang, L.; Yang, Q. LncRNA LINP1 confers tamoxifen resistance and negatively regulated by ER signaling in breast cancer. Cell. Signal. 2020, 68, 109536. [CrossRef]

172. Lin, X.; Dinglin, X.; Cao, S.; Zheng, S.; Wu, C.; Chen, W.; Li, Q.; Hu, Q.; Zheng, F.; Wu, Z.; et al. Enhancer-Driven lncRNA BDNF-AS Induces Endocrine Resistance and Malignant Progression of Breast Cancer through the RNH1/TRIM21/mTOR Cascade. Cell Rep. 2020, 31, 107753. [CrossRef] [PubMed]

173. Feng, J.; Wen, T.; Li, Z.; Feng, L.; Zhou, L.; Yang, Z.; Xu, L.; Shi, S.; Hou, K.; Shen, J.; et al. Cross-talk between the ER pathway and the lncRNA MAFG-AS1/miR-339-5p/ CDK2 axis promotes progression of ER+ breast cancer and confers tamoxifen resistance. Aging 2020, 12, 20658-20683. [CrossRef]

174. Shi, Q.; Li, Y.; Li, S.; Jin, L.; Lai, H.; Wu, Y.; Cai, Z.; Zhu, M.; Li, Q.; Li, Y.; et al. LncRNA DILA1 inhibits Cyclin D1 degradation and contributes to tamoxifen resistance in breast cancer. Nat. Commun. 2020, 11, 1-15. [CrossRef]

175. Li, H.; Zhang, G.Y.; Pan, C.H.; Zhang, X.Y.; Su, X.Y. LncRNA MAFG-ASl promotes the aggressiveness of breast carcinoma through regulating miR-339-5p/MMP. Eur. Rev. Med. Pharmacol. Sci. 2019, 23, 2838-2846. [CrossRef]

176. Jia, H.; Wu, D.; Zhang, Z.; Li, S. Regulatory effect of the MAFG-AS1/miR-150-5p/MYB axis on the proliferation and migration of breast cancer cells. Int. J. Oncol. 2020, 58, 33-44. [CrossRef] [PubMed]

177. Ding, M.; Fu, Y.; Guo, F.; Chen, H.; Fu, X.; Tan, W.; Zhang, H. Long non-coding RNA MAFG-AS1 knockdown blocks malignant progression in breast cancer cells by inactivating JAK2/STAT3 signaling pathway via MAFG-AS1/miR-3196/TFAP2A axis. Int. J. Clin. Exp. Pathol. 2020, 13, 2455-2473. [PubMed]

178. Shi, Y.-F.; Lu, H.; Wang, H.-B. Downregulated lncRNA ADAMTS9-AS2 in breast cancer enhances tamoxifen resistance by activating microRNA-130a-5p. Eur. Rev. Med. Pharmacol. Sci. 2019, 23, 1563-1573.

179. Gu, J.; Wang, Y.; Wang, X.; Zhou, D.; Shao, C.; Zhou, M.; He, Z. RETRACTED: Downregulation of lncRNA GAS5 confers tamoxifen resistance by activating miR-222 in breast cancer. Cancer Lett. 2018, 434, 1-10. [CrossRef]

180. Lee, M.-S.; Jeong, M.-H.; Lee, H.-W.; Han, H.-J.; Ko, A.; Hewitt, S.; Kim, J.-H.; Chun, K.-H.; Chung, J.-Y.; Lee, C.; et al. PI3K/AKT activation induces PTEN ubiquitination and destabilization accelerating tumourigenesis. Nat. Commun. 2015, 6, 7769. [CrossRef]

181. Xu, C.; Kong, X.; Wang, H.; Zhang, N.; Kong, X.; Ding, X.; Li, X.; Yang, Q. MTDH Mediates Estrogen-Independent Growth and Tamoxifen Resistance by Down-Regulating PTEN in MCF-7 Breast Cancer Cells. Cell. Physiol. Biochem. 2014, 33, 1557-1567. [CrossRef]

182. Song, E.-L.; Xing, L.; Wang, L.; Song, W.-T.; Li, D.-B.; Wang, Y.; Gu, Y.-W.; Liu, M.-M.; Ni, W.-J.; Zhang, P.; et al. LncRNA ADAMTS9-AS2 inhibits cell proliferation and decreases chemoresistance in clear cell renal cell carcinoma via the miR-27a3p/FOXO1 axis. Aging 2019, 11, 5705-5725. [CrossRef] [PubMed]

183. Yan, Y.; Xu, Z.; Chen, X.; Wang, X.; Zeng, S.; Zhao, Z.; Qian, L.; Li, Z.; Wei, J.; Huo, L.; et al. Novel Function of lncRNA ADAMTS9-AS2 in Promoting Temozolomide Resistance in Glioblastoma via Upregulating the FUS/MDM2 Ubiquitination Axis. Front. Cell Dev. Biol. 2019, 7, 217. [CrossRef]

184. Zhang, H.; Zhang, J.; Dong, L.; Ma, R. LncRNA ATXN8OS enhances tamoxifen resistance in breast cancer. Open Med. 2020, 16, 68-80. [CrossRef]

185. Qu, R.; Hu, C.; Tang, Y.; Yu, Q.; Shi, G. Long Non-coding RNA BLACAT1 Induces Tamoxifen Resistance in Human Breast Cancer by Regulating miR-503/Bcl-2 Axis. Cancer Manag. Res. 2020, 12, 1771-1777. [CrossRef] 
186. Ríos-Romero, M.; Cedro-Tanda, A.; Peña-Luna, M.; Mancera-Rodríguez, M.A.; Hidalgo-Pérez, L.; Cisneros-Villanueva, M.; Beltrán-Anaya, F.O.; Arellano-Llamas, R.; Jiménez-Morales, S.; Alfaro-Ruíz, L.A.; et al. FAM83H-AS1 is a potential modulator of cancer driver genes across different tumors and a prognostic marker for ER/PR + BRCA patients. Sci. Rep. 2020, 10, 1-14. [CrossRef]

187. Kim, C.Y.; Oh, J.H.; Lee, J.-Y.; Kim, M.H. The LncRNA HOTAIRM1 Promotes Tamoxifen Resistance by Mediating HOXA1 Expression in ER+ Breast Cancer Cells. J. Cancer 2020, 11, 3416-3423. [CrossRef] [PubMed]

188. Sun, W.; Xu, X.; Jiang, Y.; Jin, X.; Zhou, P.; Liu, Y.; Guo, Y.; Ma, D.; Zuo, W.; Huang, S.; et al. Transcriptome analysis of Luminal Breast Cancer Reveals a Role for LOL in Tumor Progression and Tamoxifen Resistance. Int. J. Cancer 2019, 145, 842-856. [CrossRef]

189. Mitobe, Y.; Ikeda, K.; Suzuki, T.; Takagi, K.; Kawabata, H.; Horie-Inoue, K.; Inoue, S. ESR1-Stabilizing Long Noncoding RNA TMPO-AS1 Promotes Hormone-Refractory Breast Cancer Progression. Mol. Cell. Biol. 2019, 39. [CrossRef]

190. Wang, Z.; Katsaros, D.; Biglia, N.; Shen, Y.; Loo, L.; Yu, X.; Lin, H.; Fu, Y.; Chu, W.-M.; Fei, P.; et al. ER $\alpha$ upregulates the expression of long non-coding RNA LINC00472 which suppresses the phosphorylation of NF- $\mathrm{kB}$ in breast cancer. Breast Cancer Res. Treat. 2019, 175, 353-368. [CrossRef]

191. Zhang, X.; Wang, M.; Sun, H.; Zhu, T.; Wang, X. Downregulation of LINC00894-002 Contributes to Tamoxifen Resistance by Enhancing the TGF- $\beta$ Signaling Pathway. Biochemistry 2018, 83, 603-611. [CrossRef]

192. Glinge, C.; Clauss, S.; Boddum, K.; Jabbari, R.; Jabbari, J.; Risgaard, B.; Tomsits, P.; Hildebrand, B.; Kääb, S.; Wakili, R.; et al. Stability of Circulating Blood-Based MicroRNAs - Pre-Analytic Methodological Considerations. PLoS ONE 2017, 12, e0167969. [CrossRef] [PubMed]

193. Hu, B.; Zhong, L.; Weng, Y.; Peng, L.; Huang, Y.; Zhao, Y.; Liang, X.-J. Therapeutic siRNA: State of the art. Signal Transduct. Target. Ther. 2020, 5, 1-25. [CrossRef]

194. Bajan, S.; Hutvagner, G. RNA-Based Therapeutics: From Antisense Oligonucleotides to miRNAs. Cells $2020,9,137$. [CrossRef] [PubMed]

195. Rupaimoole, R.; Slack, F.J. MicroRNA therapeutics: Towards a new era for the management of cancer and other diseases. Nat. Rev. Drug Discov. 2017, 16, 203-222. [CrossRef] [PubMed] 